\title{
Review \\ Recent Advances on Immunohistochemistry and Molecular Biology for the Diagnosis of Adnexal Sweat Gland Tumors
}

\author{
Nicolas Macagno $1,2,3, * \mathbb{C}$, Pierre Sohier $1,4,5 \oplus$, Thibault Kervarrec ${ }^{1,6,7}$, Daniel Pissaloux ${ }^{8,9}$, \\ Marie-Laure Jullie ${ }^{1,10} \oplus$, Bernard Cribier ${ }^{1,11}$ and Maxime Battistella ${ }^{1,6,12}$
}

1 French Network of Rare Skin Cancers, CARADERM, France; pierre.sohier@aphp.fr (P.S.); Thibault.Kervarrec@yahoo.fr (T.K.); marie-laure.jullie@chu-bordeaux.fr (M.-L.J.); bernard.cribier@chru-strasbourg.fr (B.C.); maxime.battistella@aphp.fr (M.B.)

2 Department of Pathology, APHM, Timone University Hospital, 13005 Marseille, France

3 Marmara Institute, Aix-Marseille University, INSERM, U1251, MMG, DOD-CET, 13005 Marseille, France

4 Faculté de Médecine, Paris Centre Santé, University of Paris, 75006 Paris, France

5 Department of Pathology, Cochin Hospital, AP-HP, AP-HP Centre-Université de Paris, 750014 Paris, France

6 Department of Pathology, Université de Tours, Centre Hospitalier Universitaire de Tours, 37000 Tours, France

7 Team: Biologie des Infections à Polyomavirus, UMR INRA ISP 1282, Université de Tours, 37000 Tours, France

8 Department of Biopathology, UNICANCER, Léon Bérard Center, 69008 Lyon, France;

Daniel.pissaloux@lyon.unicancer.fr

9 INSERM 1052, CNRS 5286, Cancer Research Center of Lyon, Lyon University, 69008 Lyon, France

10 Department of Pathology, Haut-Lévêque Hospital, CHU de Bordeaux, 33600 Bordeaux, France

11 Dermatology and Dermatopathology, Faculty of Medicine, University Hospital, University of Strasbourg, 67000 Strasbourg, France

12 Department of Pathology, Saint-Louis University Hospital, 75010 Paris, France

* Correspondence: NMacagnoMD.academic@gmail.com

check for

updates

Citation: Macagno, N.; Sohier, P.; Kervarrec, T.; Pissaloux, D.; Jullie, M.-L.; Cribier, B.; Battistella, M. Recent Advances on Immunohistochemistry and Molecular Biology for the Diagnosis of Adnexal Sweat Gland Tumors. Cancers 2022, 14, 476. https:// doi.org/10.3390/cancers14030476

Academic Editor: Selma Ugurel

Received: 9 December 2021

Accepted: 12 January 2022

Published: 18 January 2022

Publisher's Note: MDPI stays neutral with regard to jurisdictional claims in published maps and institutional affiliations.

Copyright: (c) 2022 by the authors. Licensee MDPI, Basel, Switzerland. This article is an open access article distributed under the terms and conditions of the Creative Commons Attribution (CC BY) license (https:// creativecommons.org/licenses/by/ $4.0 /)$.
Simple Summary: Cutaneous sweat gland tumors form an extremely diverse and heterogeneous group of neoplasms that show histological differentiation to the sweat apparatus. Due to their rarity, wide diagnostic range, and significant morphological overlap between entities, their accurate diagnosis remains challenging for pathologists. Until recently, little was known about the molecular pathogenesis of adnexal tumors. Recent findings have revealed a wide range of gene fusions and other oncogenic factors that can be used for diagnostic purposes and, for some, can be detected by immunohistochemistry. Among other organs containing exocrine glands, such as salivary glands, breasts, and bronchi, most of these biomarkers have been reported in homologous neoplasms that share morphological features with their cutaneous counterparts. This review aims to describe these recent molecular and immunohistochemical biomarkers in the field of sweat gland tumors.

Abstract: Cutaneous sweat gland tumors are a subset of adnexal neoplasms that derive or differentiate into the sweat apparatus. Their great diversity, rarity, and complex terminology make their pathological diagnosis challenging. Recent findings have revealed a wide spectrum of oncogenic drivers, several of which are of diagnostic interest for pathologists. Most of these molecular alterations are represented by gene fusions, which are shared with other homologous neoplasms occurring in organs containing exocrine glands, such as salivary and breast glands, which show similarities to the sweat apparatus. This review aims to provide a synthesis of the most recent immunohistochemical and molecular markers used for the diagnosis of sweat gland tumors and to highlight their relationship with similar tumors in other organs. It will cover adenoid cystic carcinoma (NFIB, MYB, and MYBL1 fusion), cutaneous mixed tumor (PLAG1 fusion), cylindroma and spiradenoma and their carcinomas thereof (NF- $\mathrm{KB}$ activation through CYLD inactivation or ALKP1 hotspot mutation), hidradenoma and hidradenocarcinoma (MAML2 fusion), myoepithelioma (EWSR1 and FUS fusion), poroma and porocarcinoma (YAP1, MAML2, and NUTM1 fusion), secretory carcinoma (ETV6, NTRK3 fusion), tubular adenoma and syringo-cystadenoma papilliferum (HRAS and BRAF activating mutations). Sweat gland tumors for which there are no known molecular abnormalities will also be briefly discussed, as well as potential future developments. 
Keywords: adenoid cystic carcinoma; NFIB; MYB; MYBL1; mixed tumor; chondroid syringoma; PLAG1; cylindroma; spiradenoma; CYLD; ALKP1; hidradenoma; MAML2; myoepithelioma; EWSR1; FUS; poroma; porocarcinoma; poroid hidradenoma; YAP1; NUTM1; secretory carcinoma; ETV6; NTRK3; tubular adenoma; syringocystadenoma papilliferum; HRAS; BRAF

\section{Introduction}

Benign and malignant cutaneous adnexal tumors are rare [1]. They span a wide variety of different diagnoses, classified according to their apocrine, eccrine, follicular, and sebaceous differentiation. Similarly, these tumors have a wide range of prognoses, including benign tumors, low-grade locally recurring tumors, and aggressive carcinomas prone to metastases.

An update of the nosology of tumors of cutaneous appendages has been proposed by the fourth edition of the WHO classification of cutaneous neoplasms [2]. At the time of its publication, many clinicopathological entities lacked a specific and robust diagnostic hallmark, but recent discoveries have revealed new biomarkers with high diagnostic value. Many of these markers are related to specific molecular alterations demonstrated in these neoplasms.

Most skin carcinomas, especially basal and squamous cell carcinomas, exhibit an ultraviolet mutational signature and a high tumor mutational burden, which are considered key oncogenic events in their initiation and progression $[3,4]$. On the contrary, adnexal tumors, which occur primarily deep in the skin, are less prone to UV exposure. Adnexal tumors are, therefore, prone to stochastic but recurrent genetic alterations, such as missense mutations and oncogenic gene fusions. Interestingly, many of these molecular alterations can also be observed in other organs containing exocrine glands, i.e., salivary glands, lacrimal glands, lung, pancreas, and breast. Therefore, cutaneous adnexal tumors are frequently analogous to extracutaneous tumors with similar morphological, phenotypic, and molecular characteristics but with different, sometimes confusing, terminologies. For example, in salivary glands, the term "cylindroma" has been used as a synonym of adenoid cystic carcinoma and, while adenoid cystic carcinoma cases of the skin are analogous to their salivary counterparts, with recurrent fusion involving the $M Y B$ gene, skin cylindromas represent a distinct tumor entity with frequent CYLD mutation. Furthermore, some of these biomarkers are related to a whole group of adnexal neoplasms since they are detected in benign and malignant cases, while some evidence suggests a multistep progression from a benign precursor with a specific molecular background to their malignant counterpart. Histopathological classifications attempted to separate the wide variety of adnexal neoplasms based on their differentiation to specific parts of the skin appendages, including apocrine, eccrine, follicular, sebaceous, and multilineage differentiation. The cell of origin remains the subject of debate and investigation for many neoplasms. The difficulty in determining the cell of origin is related in part to the biology of many fusion-driven sweat gland tumors. Indeed, chimeric fusion proteins confer a new, often aberrant, histological phenotype that lacks a physiological cellular counterpart to correlate with for classification purposes. Hopefully, most of these gene fusions are highly specific in each morphological context, being mostly restricted to a single subtype of tumor.

This review aims to provide a synthesis of the most recent immunohistochemical (Table 1) and molecular markers (Table 2) used for the diagnosis of cutaneous adnexal neoplasms with sweat gland differentiation. 
Table 1. Most recent immunohistochemistry used for the diagnosis of skin adnexal neoplasms with sweat gland differentiation.

\begin{tabular}{|c|c|c|c|}
\hline Diagnoses Considered & Antibody & Staining Pattern & Reported Positivity \\
\hline \multirow{2}{*}{ Adenoid cystic carcinoma, cylindroma, and spiradenoma } & SOX10 & nuclear & $73-100 \%$ \\
\hline & MYB & nuclear & $70-90 \%$ \\
\hline \multirow{2}{*}{ Cutaneous mixed tumor } & PLAG1 & nuclear & $87-100 \%$ \\
\hline & HMGA2 & nuclear & unknown \\
\hline \multirow{2}{*}{ Poroma, porocarcinoma, poroid hidradenoma } & YAP1 & cytoplasmic (loss) & $58-80 \%$ \\
\hline & NUT & nuclear & $29-32 \%$ \\
\hline Secretory carcinoma & panTRK & nuclear & $100 \%$ \\
\hline Syringocystadenoma papilliferum and tubular adenoma & BRAFV600E & cytoplasmic & $50-64 \%$ \\
\hline Endocrine mucin-producing sweat gland carcinoma & INSM1 & nuclear & $100 \%$ \\
\hline
\end{tabular}

Table 2. Summary of the most frequent molecular alterations in sweat gland neoplasms.

\begin{tabular}{|c|c|c|}
\hline Diagnosis & Molecular Alteration & Frequency $(\%)$ \\
\hline \multirow{2}{*}{ Adenoid cystic carcinoma } & $M Y B:: N F I B$ fusion & $73-83 \%$ \\
\hline & $M Y B L 1:: N F I B$ fusion & $20-23 \%$ \\
\hline \multirow{2}{*}{ Cutaneous mixed tumor } & PLAG1 fusion & $33 \%$ \\
\hline & $H M G A 2$ fusion & unknown \\
\hline Cylindroma & CYLD inactivation & near $100 \%$ \\
\hline \multirow{2}{*}{ Spiradenoma } & CYLD inactivation & $29 \%$ \\
\hline & ALPK1 p.V1092A mutation & $43 \%$ \\
\hline \multirow{2}{*}{ Spiradenocarcinoma } & CYLD inactivation & $8 \%$ \\
\hline & ALPK1 p.V1092A mutation & $33 \%$ \\
\hline \multirow{2}{*}{ Hidradenoma } & CRTC1::MAML2 fusion & $50-75 \%$ \\
\hline & CRTC3::MAML2 fusion & rare \\
\hline Hidradenocarcinoma & CRTC1::MAML2 fusion & unknown \\
\hline \multirow{2}{*}{ Myoepithelioma } & EWSR1 fusion & $82 \%$ \\
\hline & FUS fusion & $18 \%$ \\
\hline \multirow{2}{*}{ Poroma } & YAP1 fusion & $88 \%$ \\
\hline & NUTM1 fusion & $17-55 \%$ \\
\hline \multirow{2}{*}{ Porocarcinoma } & YAP1 fusion & $8-63 \%$ \\
\hline & NUTM1 fusion & $11-54 \%$ \\
\hline Secretory carcinoma & ETV6:NTRK3 fusion & near $100 \%$ \\
\hline \multirow{3}{*}{$\begin{array}{c}\text { Syringocystadenoma } \\
\text { papilliferum and tubular } \\
\text { adenoma }\end{array}$} & $B R A F$ p.V600E mutation & $50-64 \%$ \\
\hline & HRAS p.G13R mutation & $7-26 \%$ \\
\hline & KRAS p.G12D mutation & rare \\
\hline
\end{tabular}

We will review, in alphabetical order, adenoid cystic carcinoma (NFIB and MYB fusion), mixed tumor (PLAG1 fusion), cylindroma and spiradenoma (NF- $\mathrm{KB}$ activation through CYLD inactivation or ALKP1 hotspot mutation), hidradenoma (CRTC1/3 and MAML2 fusion), myoepithelioma (EWSR1 and FUS fusion), poroma (YAP1 and NUTM1 fusion), secretory carcinoma (ETV6 and NTRK3 fusion), tubular adenoma and syringocystadenoma papilliferum (HRAS and BRAF activating mutations). For each entity, data regarding the respective homologous extracutaneous tumors will be mentioned.

Finally, sweat gland tumors lacking known recurrent molecular abnormalities will be briefly discussed in the last paragraph of this review. 


\section{Sweat Gland Neoplasms with Recent Advances in Their Diagnosis}

\subsection{Adenoid Cystic Carcinoma}

General features: Adenoid cystic carcinoma (Figure 1) is a rare cutaneous adnexal carcinoma, characterized histologically by an epithelial and myoepithelial phenotype. Most cases demonstrate MYB::NFIB or MYBL1::NFIB gene fusions [5-7].
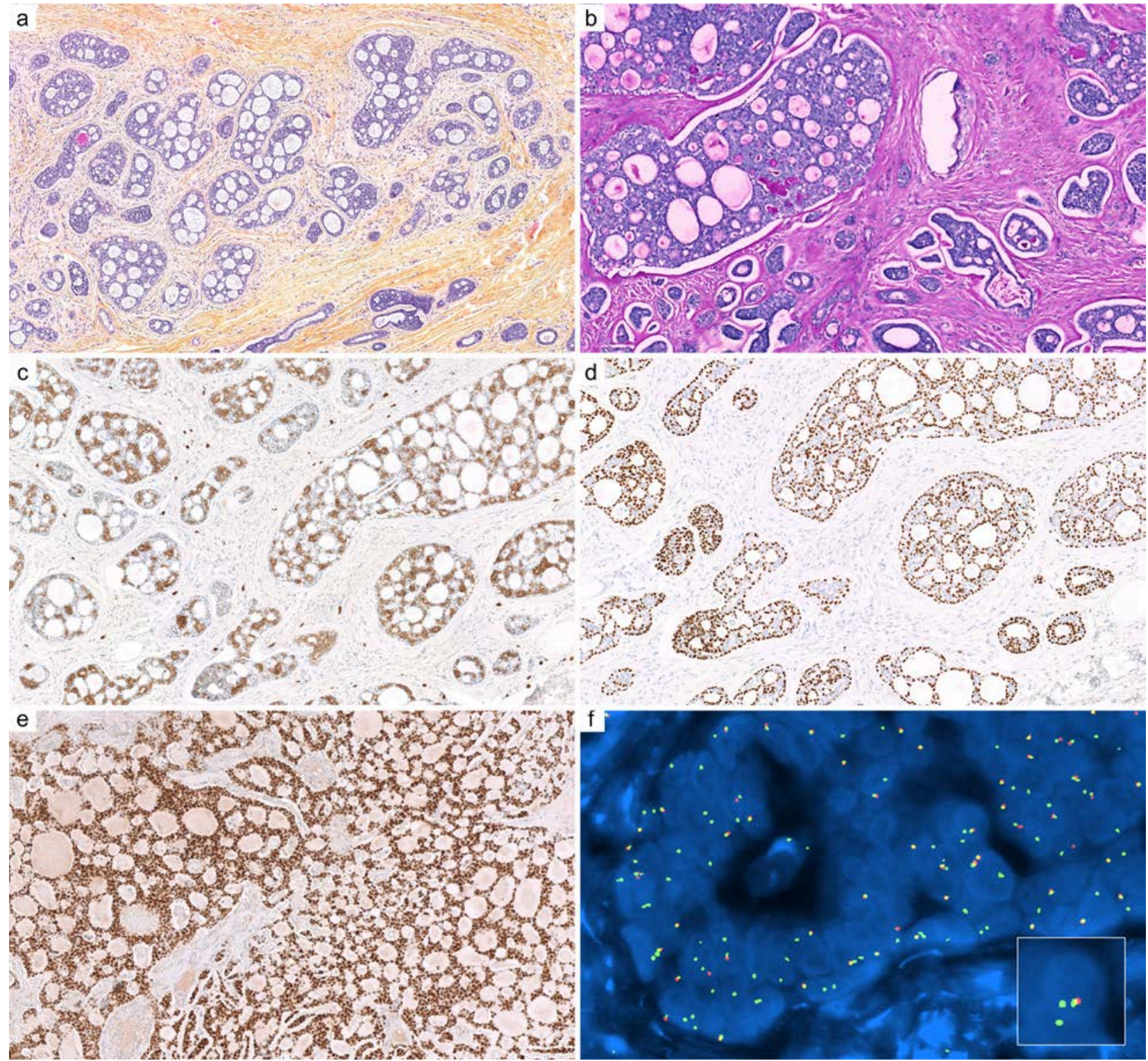

Figure 1. Cutaneous adenoid cystic carcinoma (ACC): (a) ACC is arranged in various cribriform aggregates and ductal structures (HPS, $\times 100)$; (b) periodic acid-Schiff $($ PAS) reaction highlights entrapped basement membrane material within aggregates (HPS, $\times 200)$; (c) c-KIT $(C D 117, \times 200)$ immunohistochemistry stains luminal cells; (d) immunostaining for p63 highlights outer myoepithelial cells with a discontinuous pattern $(\times 200)$; (e) SOX10 immunohistochemistry is intensely and diffusely positive in the nuclei of ACC $(\times 200)$; $(\mathbf{f})$ fluorescence in situ hybridization (FISH, break-apart probe) demonstrates a clonal rearrangement of $M Y B$ in neoplastic cells $(\times 1000)$.

Related terminology: The designation adenoid cystic carcinoma is used regardless of the location considered. Confusingly, the term 'cylindroma' has historically been used to refer to salivary gland adenoid cystic carcinoma. 
Immunohistochemistry: Most ACCs are positive for SOX10, with an intense and diffuse staining pattern [8-11]. Calponin, SMA, PS100, and p63 reveal myoepithelial differentiation, while c-KIT (CD117), EMA, CEA, and various cytokeratins label epithelial cells that line the ducts [12-14]. Immunostaining for p63 is often discontinuous compared to SOX10, which is more intense and diffuse [15]. Furthermore, c-KIT (CD117), MYB, and GATA3 are expressed in 78-100\% [13,16,17], 90\% [14], and 20\% of cases [14], respectively, but all lack specificity [12,18].

Molecular biology: Fusions of MYB or MYBL1 with NFIB are detected in 40-97\% of adenoid cystic carcinomas with very high specificity $[5,6,12,16,19,20]$. The most frequent fusions are MYB::NFIB fusion (73-83\%) and MYBL1::NFIB (20-23\%) [16,21-24], with detection of gene rearrangement in both myoepithelial and ductal epithelial cells [22]. Up to 83\% of cutaneous cases demonstrate $M Y B$ rearrangement. Extracutaneous cases lacking these recurrent alterations have been reported with alternative fusion partners (ACTN1) and amplification of $M Y B$ [25]. MYB overexpression can also occur in the absence of detectable alteration, suggesting alternative unknown mechanisms in a subset of cases. MYB protooncogene, transcription factor $(M Y B)$, and MYB proto-oncogene like 1 (MYBL1) are genes mapped on chromosomes 6 and 8, respectively. MYB and MYBL1 rearrangements and amplification cause cell proliferation [26] through the dysregulation of MYB target genes, which are involved in the control of cell cycle: NSR, MET, EGFR, IGF1R, and IGF2 (89). The NOTCH pathway genes are commonly altered in advanced adenoid cystic carcinoma and can be targeted by specific therapies [27].

Discordant or controversial data: Contrary to the high specificity reported by numerous studies $[5,6,12,16,19,20], M Y B:: N F I B$ fusions have been reported in tumors diagnosed as wild-type CYLD cutaneous cylindroma in a single report [28], but this finding was not further confirmed [29]. Since cylindroma and adenoid cystic carcinoma show significant histopathological overlap, the possibility of $M Y B$ fusion in bona fide cutaneous cylindroma is highly questionable.

\subsection{Cutaneous Mixed Tumor (Chondroid Syringoma)}

General features: Cutaneous mixed tumor (chondroid syringoma, Figure 2) is a multiphenotypic epithelial, myoepithelial, and mesenchymal neoplasm.
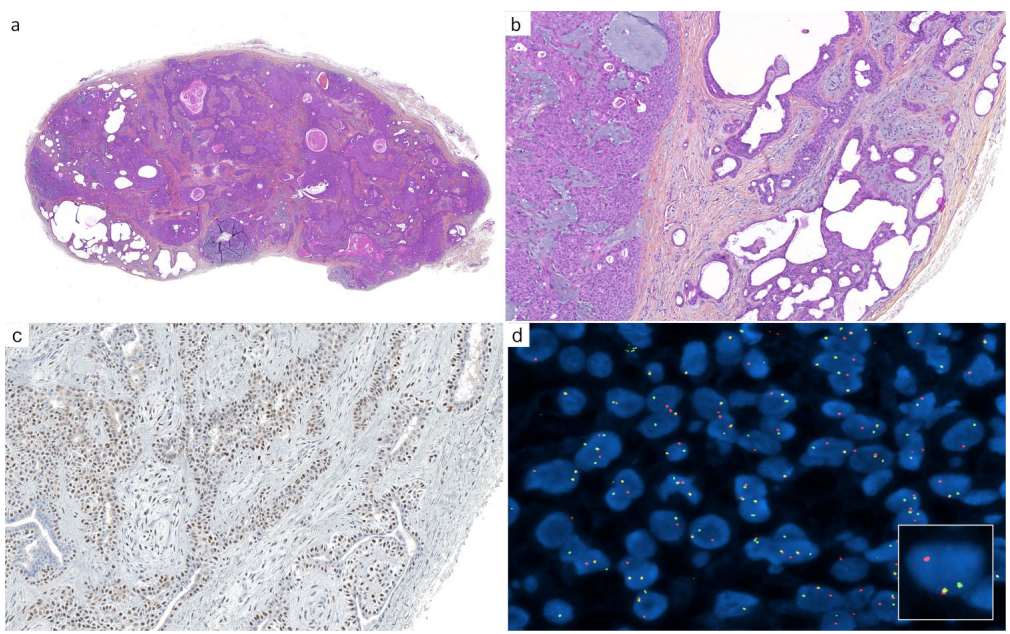

Figure 2. Cutaneous mixed tumor (chondroid syringoma): (a) cutaneous mixed tumor presenting as a circumscribed nodule, with cysts, ducts, nodules, and abundant stroma $(\times 25)$; (b) higher magnification reveals different cell populations: myoepithelial aggregates (left), elaborated and cystic ductal structures (right), and mesenchymal cells associated with fibrous, fibromyxoid, and myxoid stroma ( $\times 100)$; (c) PLAG1 immunohistochemistry: diffuse nuclear staining is present, notably in the myoepithelial component $(\times 200)$; (d) fluorescence in situ hybridization (FISH, break-apart probe) demonstrates a clonal PLAG1 gene rearrangement $(\times 1000)$. 
The stroma is often fibrous, myxoid, chondroid, lipogenic, and osteogenic, imparting a distinctive morphology. Apocrine and eccrine-type cutaneous mixed tumors have been described. In addition to the sweat gland component, areas of follicular and/or matrical differentiation are frequent. Myoepithelioma is a related neoplasm lacking ductal differentiation (cf. myoepithelioma).

Related terminology: The homologous neoplasm in the salivary gland, breast, and lung is called pleomorphic adenoma.

Immunohistochemistry: Like adenoid cystic carcinoma, a cutaneous mixed tumor shows epithelial and myoepithelial differentiation but also a stromal component. The panel of antibodies to highlight its multiple cell populations includes SOX10, p63, PS100, calponin, SMA, EMA, c-KIT, CEA, and various cytokeratins [12-14]. Follicular differentiation stains with BerEP4 and PHDLA1. Although not evaluated in cutaneous cases, SOX10 is highly sensitive for the diagnosis of pleomorphic adenoma but lacks specificity [8,9]. A more specific marker is PLAG1 (clone 3B7), which is overexpressed in 87 to $100 \%$ of cutaneous mixed tumors, while rare cases show HMGA2 expression [30,31]. Since cutaneous mixed tumors of eccrine-type lack PLAG1 expression, it is unclear if cutaneous mixed tumors of apocrine and eccrine-type belong to the same spectrum until more studies are conducted [30]. PLAG1 is not expressed in soft tissue myoepithelioma lacking ductal structures [32], and has not been specifically tested in cutaneous myoepithelioma. Consistent with these findings, PLAG1 and HMGA2 show high sensitivity and specificity for the diagnosis of salivary pleomorphic adenoma and its related carcinoma [33-35]. The precise performance of PLAG1 and HMGA2 in skin cases requires larger studies.

Molecular biology: Recurrent rearrangements of PLAG1 are detected in 33\% of cutaneous mixed tumors by FISH [31], which is a developmentally regulated zinc-finger protooncogene. PLAG1 activation through gene fusion typically occurs due to promoter swapping from various fusion partner genes that are ubiquitously expressed, such as CTNNB1, LIFR, and CHCHD7. This explains why pleomorphic adenomas of the salivary gland demonstrate a wide range of PLAG1 and HMGA2 fusions: CTNNB1::PLAG1, LIFR::PLAG1, CHCHD7::PLAG1, TCEA1::PLAG1, HMGA2::FHIT, HMGA2::NFIB, and HMGA2::WIF1. A1though NDRG1::PLAG1 and TRPS1::PLAG1 fusions have been described in cutaneous cases [31], another study did not detect the fusions found in the salivary gland in cutaneous cases, suggesting different gene rearrangements or mechanisms [36]. To date, no HMGA2 fusion has been reported in cutaneous mixed tumors. More studies are required to define more precisely the genetic landscape of cutaneous mixed tumors and, in particular, their relationship with myoepithelioma when their myoepithelial component is predominant (cf. myoepithelioma).

Discordant or controversial data: A PHF1::TFE3 fusion transcript was detected in one case morphologically diagnosed as malignant chondroid syringoma [37]. However, it remains to be determined whether this tumor actually belonged to the mixed tumor spectrum or was in fact a superficial ossifying fibro-myxoid tumor.

\subsection{Cylindroma and Spiradenoma}

General features: Cylindroma and spiradenoma (Figure 3) are related epithelial and myoepithelial skin neoplasms, associated with activation of the NF-kB pathway, which is triggered by inactivation of CYLD or ALPK1 mutations. Spiradenoma differs from cylindroma by its nodular architecture and lymphocytic infiltrate. On rare occasions, both neoplasms show a morphological and phenotypical overlap with adenoid cystic carcinoma. Most cases occur sporadically; however, some cases arise in the context of a predisposition syndrome known as Brooke-Spiegler syndrome. Multiple cylindromas, spiradenomas, trichoepitheliomas, and basal cell salivary gland tumors occur in this autosomic dominant disorder linked to CYLD mutations. 

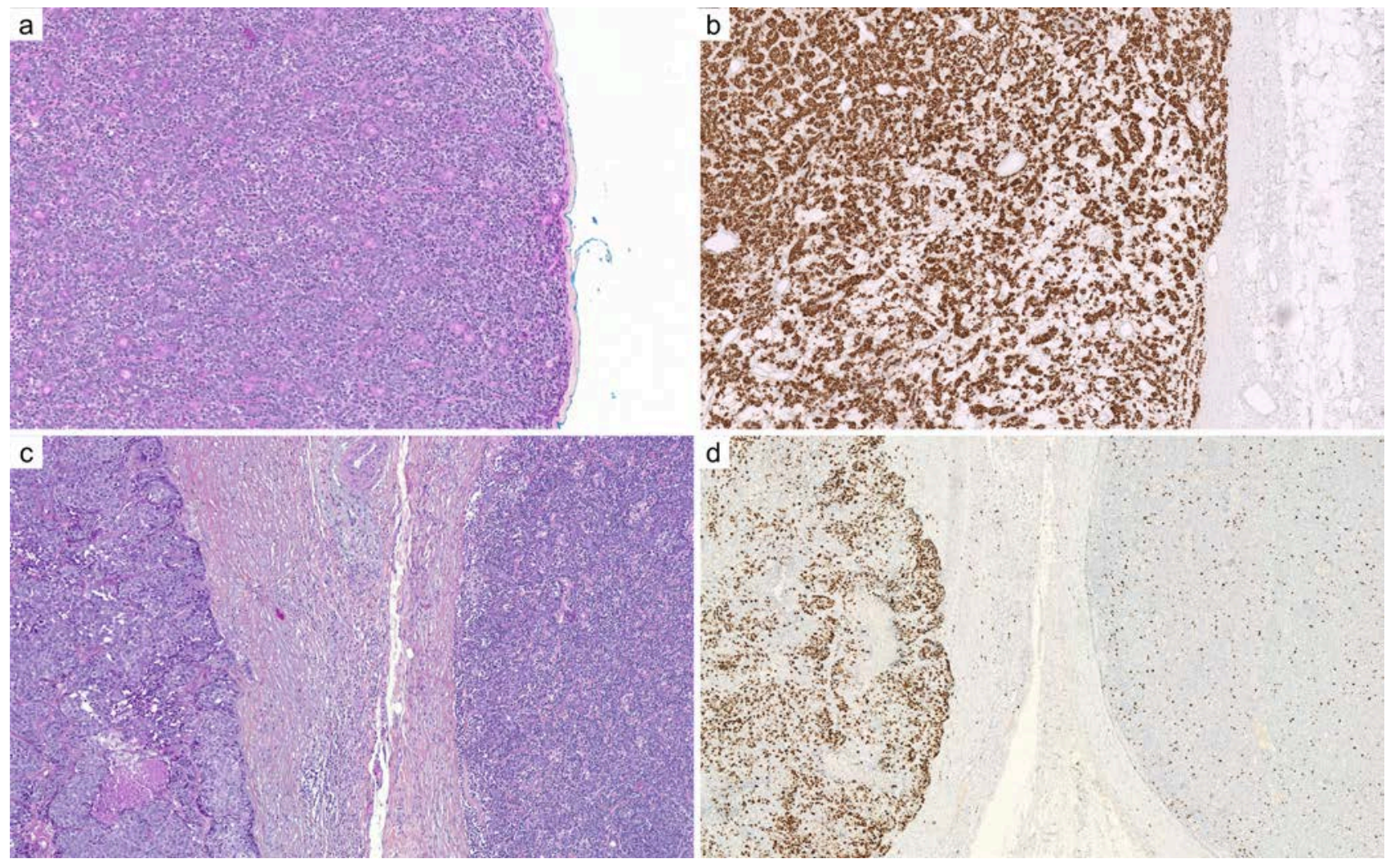

Figure 3. Transformation of spiradenoma into spiradenocarcinoma: (a) benign spiradenoma exhibits a dense nodular arrangement of myoepithelial and epithelial cells, intermingled with scattered lymphocytes (×100); (b) SOX10 immunohistochemistry diffusely and intensely stains the nuclei of spiradenoma, similar to adenoid cystic carcinoma $(\times 100)$; (c) malignant transformation of a spiradenoma (right) into a spiradenocarcinoma (left): the malignant component demonstrates loss of architecture, pleomorphism, necrosis, cell crowding, increased mitotic activity, and loss of lymphocytic infiltrate ( $\times 100)$; (d) Ki67 immunohistochemistry: the labeling index is higher in the spiradenocarcinoma (left) compared to the precursor spiradenoma (right) $(\times 100)$.

Related terminology: Homologous neoplasms in the salivary gland and breast are called basal cell adenoma (membranous variant of) and adenocarcinoma. Confusingly, the term 'cylindroma' has historically been used in the salivary gland to describe adenoid cystic carcinoma.

Immunohistochemistry: Cylindroma and spiradenoma staining patterns are similar to ACC [12-14]: SOX10 is intensely expressed, myoepithelial cells express calponin, SMA, and p63, while luminal cells express c-KIT (43\%), EMA, CEA, and cytokeratins. MYB is expressed and cannot help differentiate from other sweat gland tumors [14]. Spiradenoma is infiltrated by CD3+ lymphocytes and CD1a+ Langerhans cells [38]. A distinctive claudin4 staining pattern was found compared to poroma, syringoma, and hidradenoma in a single study [39]. The malignant transformation of spiradenoma is associated with an increase in Ki67 [40] and loss of MYB expression [41].

Molecular biology: Spiradenoma and cylindroma are related to oncogenic activation of the NF- $\mathrm{B}$ pathway, triggered by mutually exclusive mutations of ALPK1 and CYLD [29]. A wide range of CYLD mutations affect coding and splicing, resulting in inactivation of CYLD [42]. Most cases of cylindroma carry germline or somatic CYLD mutations compared to approximately a third of cases of spiradenoma [29]. Disruptive mutations in DNMT3A have also been described in cylindroma [29]. ALPK1 mutations involve predominantly a hotspot in the alpha-kinase domain (p.V1092A) and are detected in 43\% and $28 \%$ of spiradenomas and spiradenocarcinomas, respectively. Consistent with a model 
of progression and transformation from precursor spiradenoma, loss-of-function TP53 mutations are restricted to spiradenocarcinoma [43].

Discordant or controversial data: MYB fusions are highly specific and are considered the hallmark of ACC $[5,6,12,16,19,20]$, and have not been detected in CYLD-defective cylindroma [44]. A single study has reported that tumors diagnosed as CYLD-proficient dermal cylindroma demonstrated $M Y B$ fusions [28], which was not confirmed in a subsequent large-scale study [29] (cf. adenoid cystic carcinoma). Similar to adenoid cystic carcinoma, CYLD-defective cylindromas, however, demonstrate upregulation and overexpression of MYB and its target genes [44], suggesting the involvement of alternative mechanisms than MYB fusion [29]. CYLD mutations have recently been described in a subset of high-risk HPV-positive head and neck squamous cell and anal carcinomas, which show histological features close to cylindroma and have been designated as CYLD-mutant cylindroma-like basaloid carcinoma $[45,46]$.

\subsection{Hidradenoma}

General features: Hidradenoma (Figure 4) is a dermal-based nodular neoplasm that exhibits clear, squamous, ductal, oxyphilic, and mucous-producing cells arranged in various proportions. Most cases demonstrate MAML2 gene fusion. Malignant cases are called hidradenocarcinoma, a subset of which results from the transformation of a precursor hidradenoma.
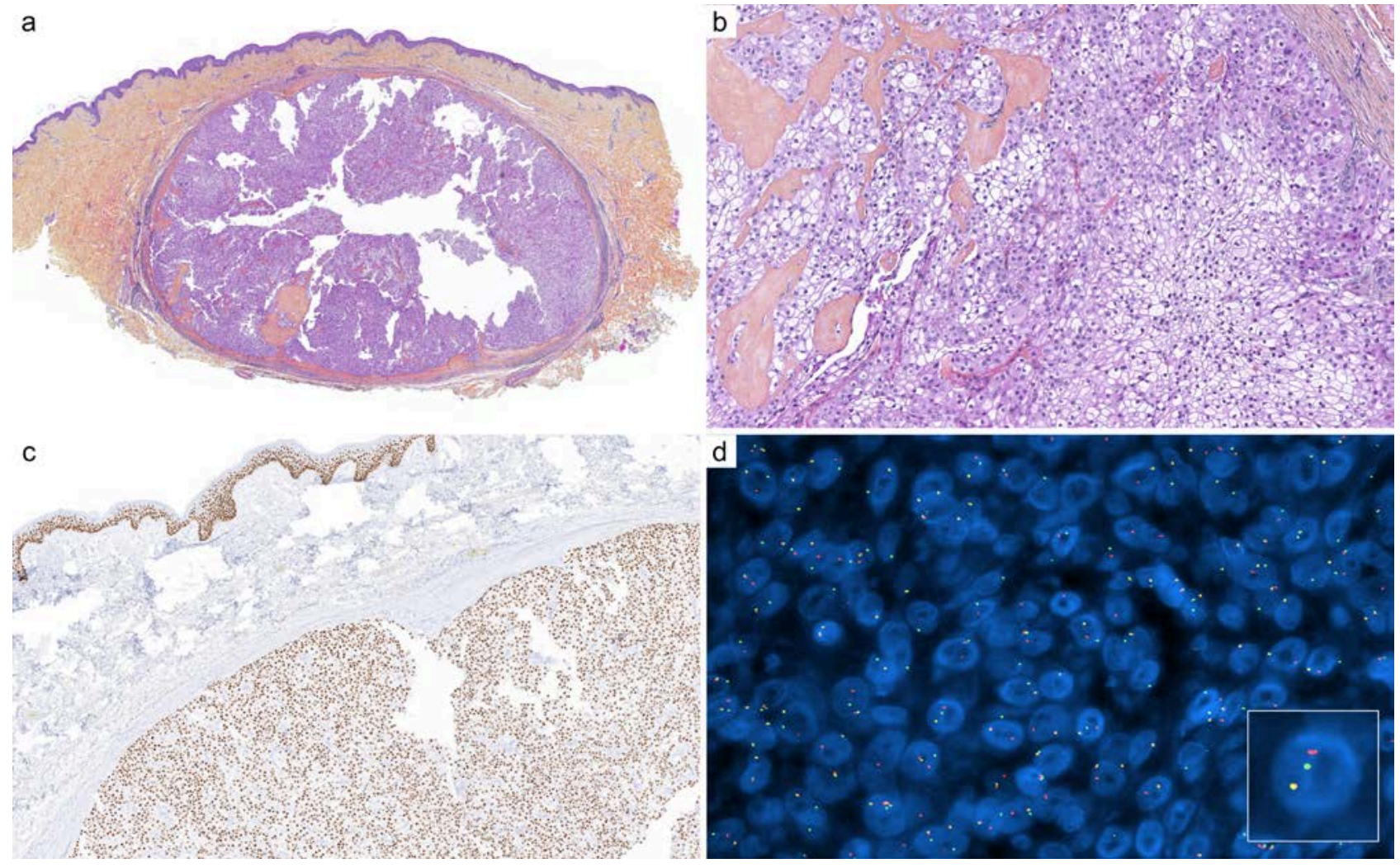

Figure 4. Cutaneous hidradenoma: (a) well-circumscribed nodular neoplasm $(\times 25)$; (b) clear cell cytology and fibrous hyaline stroma $(\times 200)$; (c) immunohistochemistry for p63 is usually intense and diffuse $(\times 100)$; (d) fluorescence in situ hybridization (FISH, break-apart) demonstrates a clonal rearrangement of MAML2 $(\times 1000)$.

Related terminology: The homologous neoplasm in the breast, salivary gland, lung, and pancreas is mucoepidermoid carcinoma.

Immunohistochemistry: Hidradenoma does not demonstrate a specific phenotype due to the combination of different types of cells. They express strongly and diffusely 
p40, p63, CK5/6, and AE1/AE3, while S100 and SMA are usually negative [47,48]. Immunostaining for EMA and CEA highlights ductal differentiation when present. Data on SOX10 expression are currently lacking, but, in our experience, SOX10 is constantly negative. Higher Ki67 and PHH3 labeling index and p53 expression have been reported in malignant cases [49].

Molecular biology: Half to $75 \%$ of the cases of hidradenoma have CRTC1::MAML2, and, more rarely, CRTC3::MAML2 fusions [50]. Similarly, salivary gland mucoepidermoid carcinoma demonstrates 34-70\% of CRTC1::MAML2, and, more rarely, CRTC3::MAML2 fusions [51-53]. Hidradenocarcinomas also demonstrate MAML2 rearrangement but with lower frequencies than their benign counterparts, while a subset carries TP53, AKT1, PI3KCA mutations, and Her2/neu amplification [54,55]. CREB-related transcriptional coactivator 1 (CRTC1) is located on chromosome 19 and activates cAMP-responsive element binding protein (CREB) signaling. Mastermind-like 2 (MAML2) is located on chromosome 11 and is associated with the Notch signaling pathway. EGFR overexpression has been found in the whole spectrum of cutaneous hiradenoma, namely hidradenocarcinoma, atypical hidradenoma, and hidradenoma [49]. However, a study investigating the amplification of EGFR in cutaneous cases lacked to demonstrate a clear correlation between the protein expression and the amplification of EGFR. Nonetheless, the EGFR signaling could still represent the mechanism of action of the CRTC1::MAML2 fusion protein since the CRTC1 portion of the chimeric protein acts on AREG, which is a ligand of EGFR. In addition, some cases of salivary mucoepidermoid carcinoma that lack CRTC1::MAML2 fusion rather demonstrate amplification and overexpression of EGFR and higher grade [56]. In this setting, therapies targeting the EGFR signaling axis are being investigated, such as Gefitinib [57]. Considering the current lack of data, the exact incidence of MAML2 gene fusion in hidradenoma and hidradenocarcinoma requires more studies.

Discordant or controversial data: EWSR1::POU5F1 fusion has been described in tumors diagnosed as hidradenoma in a single report [58] but has not been further confirmed [59]. A subsequent study has shown that this fusion defined a subset of myoepithelial tumors that can be mistaken for hidradenoma due to an extensive clear cell morphology [60] (cf. myoepithelioma).

\subsection{Microcystic Adnexal Carcinoma}

General features: Microcystic adnexal carcinoma (MAC) predominantly affects the sun-exposed area of the head and neck and has a high recurrence rate, slow growth, and low metastatic potential. MAC is an asymmetric and deeply infiltrative tumor that can present three components arranged in a vertical gradient, some of which may be lacking: small keratinizing cysts on the surface, solid aggregates in the center of the lesion, and, finally, deep tubular structures. As the histology of MAC in the superficial part of the skin resembles the histology of syringoma and basal cell carcinoma, an accurate diagnosis of MAC can be difficult on superficial biopsy. No specific molecular or immunohistochemical hallmark has yet been discovered.

Related terminology: Microcystic adnexal carcinoma is specific to the skin and lacks a homologous neoplasm in other organs. Solid carcinoma, reported in a series of 14 cases, may represent a variant of microcystic adnexal carcinoma [61]. A low-grade variant has recently been described as microcystic adnexal adenoma [62]. Hamartomatous lesions similar to MAC but with benign behavior have recently been reported in MALTA syndrome related to germline $\mathrm{MYH9}$ mutations [63].

Immunohistochemistry: Immunostains aim to differentiate between MAC, desmoplastic trichoepithelioma, basal cell carcinoma, and squamous cell carcinoma. In this setting, BerEP4, p63, and Ki67 can be used. BerEP4 shows negative or very infrequent staining in $\mathrm{MAC}$, including the solid variant, while strong BerEP4 staining suggests basal cell carcinoma [61,64-68]. Immunostaining for p63 highlights scattered positive cells in the upper part of the neoplasm, but the deepest part of the MAC can be negative. On the contrary, p63 expression is diffuse in basal and squamous cell carcinoma $[69,70]$. Low-proliferation, 
i.e., $\mathrm{Ki} 67<5 \%$, favors MAC over basal and squamous cell carcinoma [68,71]. The luminal cells of the ductal structures are stained with CK7 and CEA, but this does not discriminate between other sweat gland neoplasms with ductal differentiation. PHLDA1 does not help to differentiate MAC from DTE, CK20 is usually negative [72], and SOX10 is almost always negative [73].

Molecular biology: Analysis of mutation burden, UV signature, mutational status of 400 cancer-relevant genes, and copy number variations showed few recurrent somatic mutations and, in most cases, a lack of an ultraviolet signature, a counterintuitive finding regarding the preferential occurrence of MAC in chronically sun-exposed skin [12]. The same study reported inactivating TP53 mutations and frame-preserving indel mutations located in the kinase domain of $J A K 1$, copy number alterations with gain of $J A K 2, M A F$, $M A F B$, JUN, or FGFR1, and loss of CDKN2A. These data were consistent with another study in which sequencing indicated a mutation of TP53 with loss of CDKN2A and CDKN2B in metastatic MAC [74]. Another study reported that, unlike basal cell carcinoma, Hedgehog signaling was not significantly altered in MAC [75]. Considering its lack of UV signature and since no oncogenic mutation was identified in one third of the cases in the largest study to date, more studies are required, including the detection of gene fusions, to reveal the genomic landscape of MAC.

\subsection{Myoepithelioma}

General features: Myoepithelioma (Figure 5) is a rare neoplasm that occurs on the skin, soft tissue, salivary gland, and breast that is composed exclusively of myoepithelial cells. Half of extracutaneous cases are associated with various rearrangements of EWSR1 or FUS [76]. Unlike mixed tumors, myoepitheliomas are defined by the lack of ductal structures. Half of cutaneous cases exhibit a distinctive skin-specific syncytial sheet-like pattern and harbor a EWSR1::PBX3 fusion. Malignant cases are extremely rare.

Related terminology: The term myoepithelioma is used regardless of the organ considered. Depending on the classification, myoepithelial tumors are considered mesenchymal.

Immunohistochemistry: There is no specific immunostain for myoepithelial differentiation. Myoepitheliomas generally exhibit the expression of cytokeratins, S100 (70-80\%), SOX10 (30-82\%), calponin (86\%), EMA (65\%), GFAP (45\%), SMA (35\%), desmin (15\%), and p63 (15\%) [77-79]. Syncytial myoepitheliomas lack cytokeratins expression [80].

Molecular biology: EWSR1 belongs to the TET family of proteins, a highly conserved group of multifunctional, RNA-binding proteins that includes fused in sarcoma (FUS). EWSR1 and FUS are related in both structure and function, are expressed in most cell and tissue types, and serve a multifunctional purpose and predominantly reside in the nucleus. Fusion proteins involving EWSR1 and FUS act as aberrant transcription factors (EWSR1/FUS providing the transcriptional activation domain and the other gene involved usually contributing the DNA-binding domain). While EWSR1 gene fusions are lacking in cutaneous mixed tumors, many recurrent gene fusions involving the EWSR1 and FUS genes have been reported in cutaneous and soft tissue myoepithelioma [60], with a proportion of $82 \%$ and $18 \%$, respectively. EWSR1::PBX3 fusions are more frequent in syncytial myoepithelioma compared to other cutaneous myoepitheliomas [80-82]. In extracutaneous myoepitheliomas, EWSR1::POU5F1 and EWSR1::PBX3 are the two most frequent fusions [76], while FUS::KLF17, EWSR1::PBX1, EWSR1::ZNF444, EWSR1::KLF15, FUS::POU5F1, EWSR1::KLF17, EWSR1::FUS, EWSR1::ATF1, and EWSR1::VGLL1 are less frequent $[60,76,83-88]$. POU5F1-rearranged myoepitheliomas show a distinctive clear cell appearance that can be mistaken for hidradenoma, and PBX1-rearranged myoepitheliomas show sclerosis [60]. Loss of SMARCB1 (INI1) is observed in a subset of malignant cases but has not been reported on the skin [89-91]. 
a
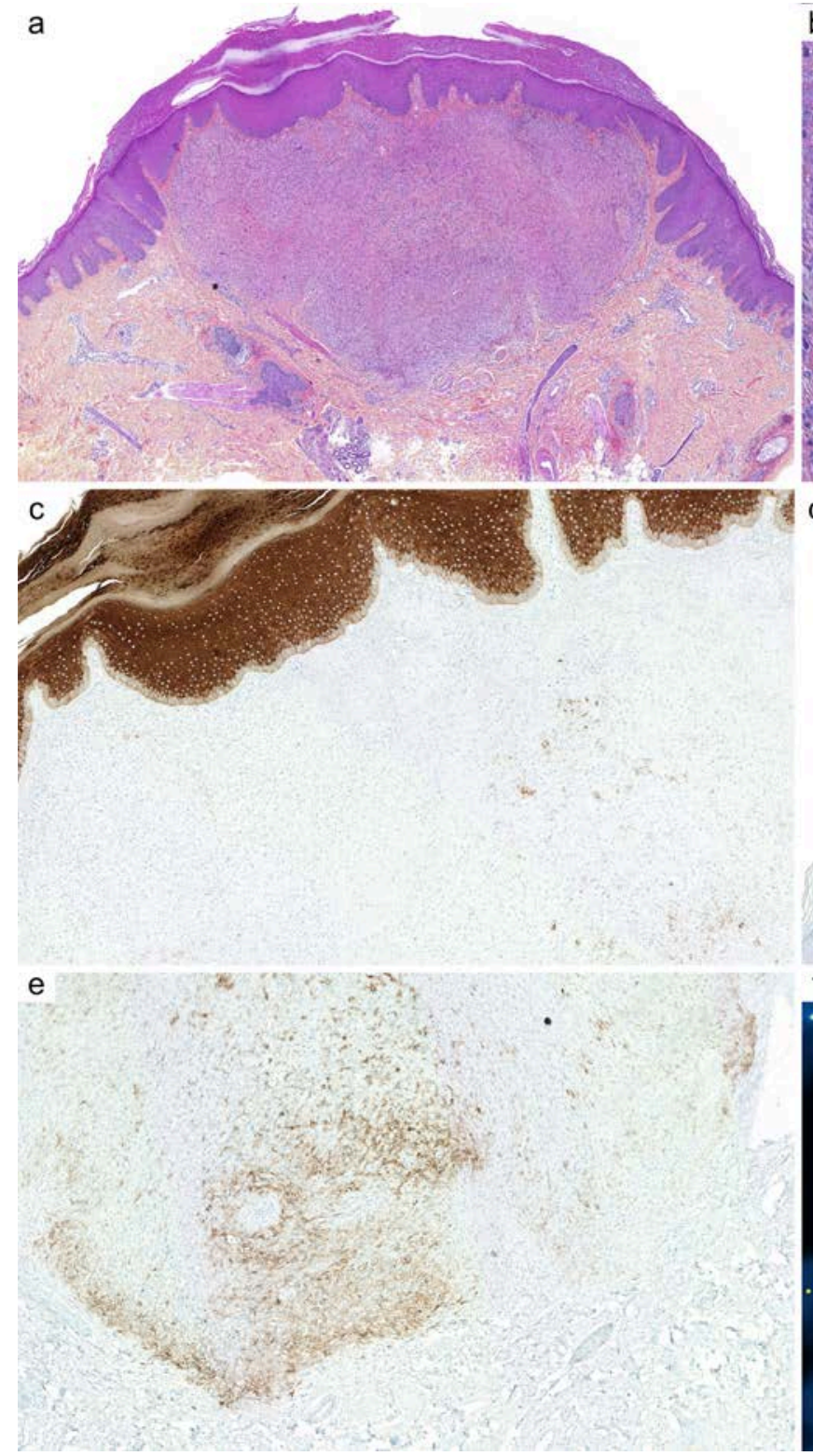

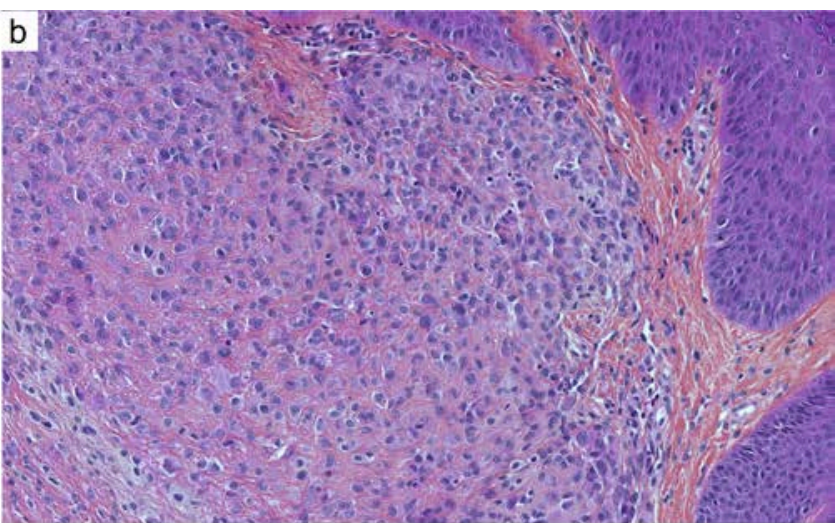

d
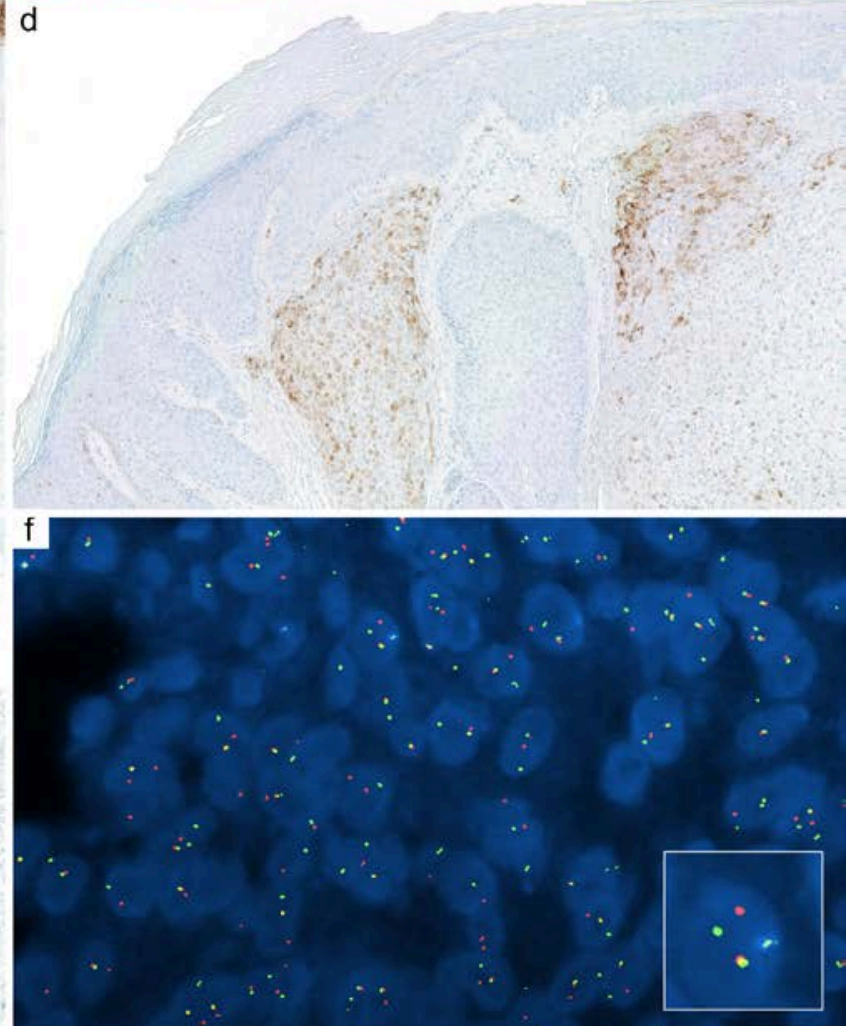

Figure 5. Cutaneous syncytial myoepithelioma: (a) this variant of myoepithelioma occurs predominantly in the superficial dermis $(\times 25)$; (b) epithelioid and plasmacytoid cells are arranged in sheets with little or no intervening stroma $(\times 200)$; (c) AE1/AE3 immunohistochemistry is most often negative or stains only scattered isolated cells $(\times 100)$; (d) PS100 $(\times 100)$ and (e) EMA immunohistochemistry stains various populations of cells $(\times 100)$; (f) fluorescence in situ hybridization (FISH, break-apart) demonstrates clonal rearrangement of EWSR1 gene $(\times 1000)$.

Discordant or controversial data: EWSR1::POU5F1 translocation is frequent in a subset of myoepithelial tumors with frequent extensive clear cell morphology that can be mistaken for hidradenoma [60]. In this context and before the description of this fusion in clear cell myoepithelial neoplasms, EWSR1::POU5F1 had been reported in tumors diagnosed as hidradenoma in a single report [58] but was not confirmed afterwards [59] (cf.: hidradenoma). PLAG1 fusions have been reported in myoepithelioma with ductal structures, and it is not yet clear whether these neoplasms are distinct from mixed tumors with a prominent myoepithelial component [92]. 


\subsection{Poroma}

General features: Eccrine poroma (Figure 6) is morphologically characterized by a dual population of cells, namely poroid and cuticular cells, ductal differentiation, and demonstrates gene fusions involving YAP1, MAML2, and NUTM1.
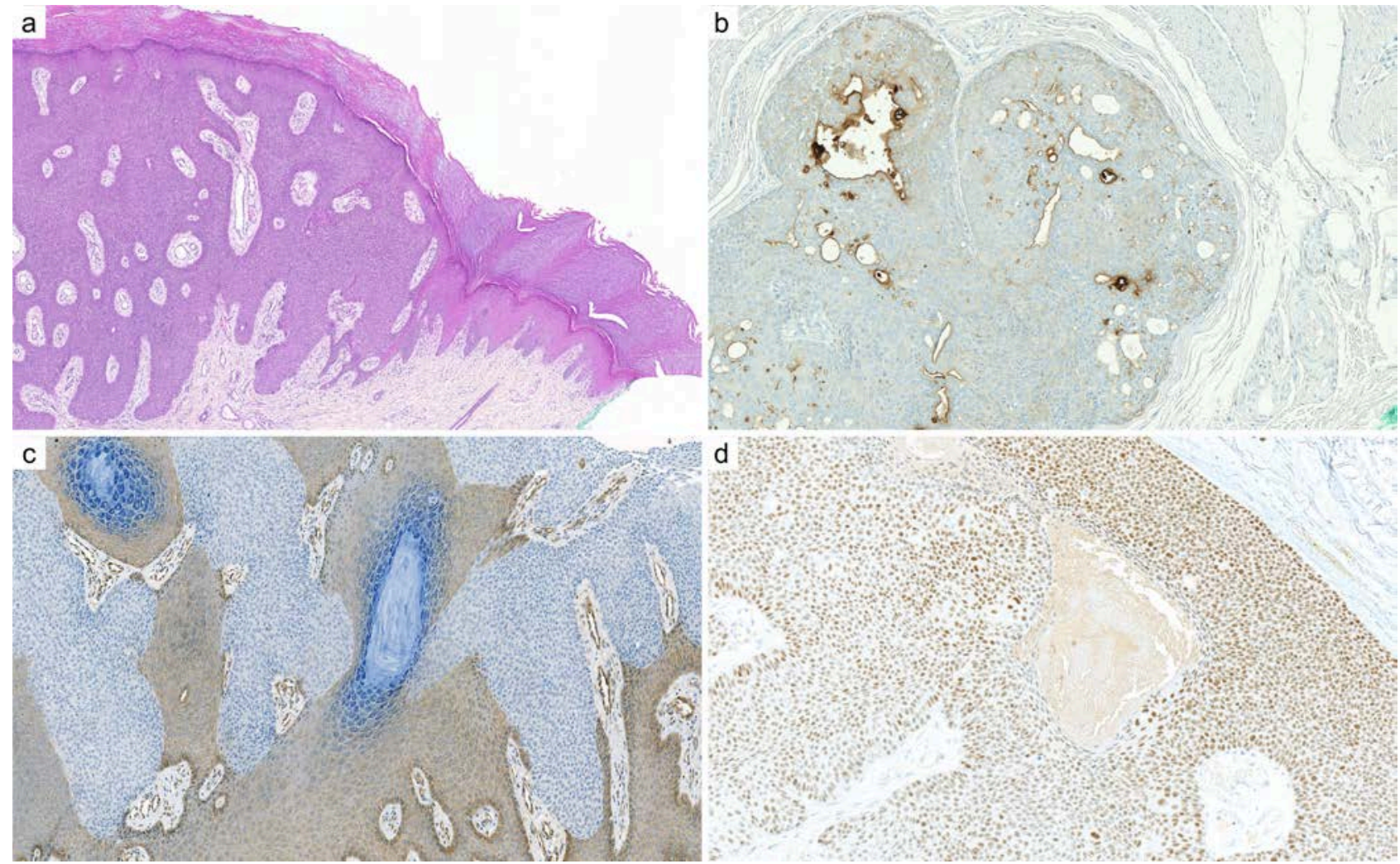

Figure 6. Eccrine poroma: (a) cutaneous eccrine poroma is composed of a population of poroid cells, with a sharp demarcation with adjacent epidermis, inconspicuous ducts, and numerous dilated vessels in the papillary dermis $(\times 25)$; (b) CEA immunohistochemistry highlights the ductal differentiation ( $\times 200)$; (c) YAP1 (c-terminal) immunohistochemistry shows a clonal loss of expression in poroid cells compared to the adjacent epidermis, which suggest a YAP1-fusion $(\times 200)$; (d) NUT immunohistochemistry demonstrates diffuse nuclear staining when a NUTM1 gene fusion is involved, which is more frequent in the poroid hidradenoma variant $(\times 200)$.

Related terminology: The malignant counterpart of poroma is called porocarcinoma. The homologous malignant neoplasm in the salivary gland is called squamoid porocarcinoma. Dermal-based nodular poroma is called poroid hidradenoma [93].

Immunohistochemistry: The most recent immunohistochemical markers are YAP1 (clone D8H1X) and NUT (clone C52B1) [94-96]: loss of cytoplasmic expression of the cterminal portion of YAP1 and/or aberrant nuclear expression of NUT both suggest the presence of an underlying gene fusion. YAP1 and NUT cannot discriminate between benign poroma and malignant porocarcinoma. Although preliminary data have suggested a high diagnostic specificity with respect to most differential diagnoses, the exact specificity of YAP1 is still being investigated. NUT immunohistochemistry is highly specific for NUTM1rearranged cutaneous poroid neoplasms, and, among these, poroid hidradenoma shows the most frequent expression of NUT [95]. In general, NUT immunohistochemistry has $100 \%$ specificity and $87 \%$ sensitivity to detect NUTM1 fusion [97]. NUT immunohistochemistry cannot discriminate between the different types of fusions, i.e., YAP1::NUTM1, WWTR1::NUTM1, and BRD3/4::NUTM1 fusions, the latter occurring in NUT-midline carcinoma and exceptional cases of primary cutaneous carcinoma $[98,99]$. A higher Ki67 
labeling index and aberrant expression of p53, RB, and p16 are more frequent in porocarcinoma [100-102]. Other stains, including CAE, EMA, c-KIT [103,104], and luminal cytokeratins, highlight ductal differentiation with variable sensitivity in poroma and porocarcinoma [105]. AE1/AE3 and cytokeratins 1, 5, 8, 10, and 14 are variably expressed within poroid and cuticular cells but lack specificity [106]. GATA3 [107], SOX10 [48], and GCDFP-15 [108] are usually negative.

Molecular biology: Recurrent YAP1 rearrangements have been detected in 88\% and $63 \%$ of cases of poroma and porocarcinoma, respectively [109], with subsequent reports detecting a YAP1::MAML2 fusion in porocarcinoma [110] and in parotid gland squamoid porocarcinoma [111]. Yes1 associated transcriptional regulator (YAP1) is a transcriptional coactivator whose activity is controlled by the Hippo signaling pathway, regulating homeostasis and regeneration. YAP1 is also involved in cancer initiation, aggressiveness, metastasis, and therapy resistance [112]. Other fusions include YAP1::NUTM1 and WWTR1::NUTM1. Consistent with immunohistochemical data, a single study reported that YAP1::NUTM1 fusion was more common in benign and malignant poroid hidradenoma than in poroma and porocarcinoma [95]. BRD3/4::NUTM1 fusion has been described in exceptional cases of primary or metastatic cutaneous adnexal carcinoma $[98,99]$. All the fusions harbor the Nterminal TEAD-binding domain of YAP1 or WWTR1 and the MAML2- or NUTM1-derived regions that interact with transcriptional coactivators CBP and p300 [109]. Porocarcinomas also carry mutations involving oncogenes and tumor suppressor genes, such as $C D K N 2 A$, EGFR, ERBB2, FGFR3, HRAS, KRAS, NRAS, PIK3CA, TP53, and RB1 [109,113-115]. A recent cohort of morphologically diagnosed porocarcinoma reported a high mutational burden related to UV exposure, recurrent copy number alterations, including losses in chromosomal regions containing $B R C A 2$, and deleterious alterations in multiple homologous recombination repair pathway components. Although gene fusions in this study were not tested to confirm diagnosis, these data encourage investigation of targeting the p53 axis, PARP inhibition, and immunotherapy in the treatment of porocarcinoma [116].

\subsection{Secretory Carcinoma}

General features: Cutaneous secretory carcinoma (Figure 7) is a rare cutaneous NTRKrearranged carcinoma that shows distinctive intracytoplasmic secretory vacuoles and bubbly extracellular eosinophilic secretions.

Related terminology: Secretory carcinoma occurs in the breast, salivary gland, lacrimal gland, lung, and skin. Cutaneous terminology includes 'primary cutaneous mammary analogue secretory carcinoma' (MASC) and 'mammary-type secretory carcinoma of the skin'.

Immunohistochemistry: NTRK fusions can be detected by immunohistochemistry using a panTRK antibody (clone EPR 17341) with various performances and staining patterns, with a sensitivity up to $100 \%$ for secretory carcinoma [117-119]. When fusion involves ETV6, TRK immunohistochemistry is expected to stain the nucleus, while the cytoplasm and/or membrane are stained when alternative fusion partners are involved [120]. Other positive stains include SOX10, MUC4, S100, Mammaglobin, and STAT5A, while TTF1, DOG1, and p63 are negative [8,121,122].

Molecular biology: Independent of the organ considered, most cases of secretory carcinoma are associated with ETV6::NTRK3 fusion $[123,124]$. The neurotrophic receptor tyrosine kinase (NTRK) family of genes includes NTRK1, NTRK2, and NTRK3, which regulate cell survival and differentiation. NTRK gene fusions have been shown to be actionable genomic events with the demonstration of highly efficacious outcomes with the use of TRK kinase inhibitors, such as larotrectinib and entrectinib [125]. An alternative NFIX::PKN1 fusion has also been described [126]. Owing to its simple genomics, secretory carcinoma demonstrates low mutation burden and low copy number alterations [127]. The ETV6::NTRK3 fusion is not specific and is detected in infantile fibrosarcoma, cellular mesoblastic nephroma, melanocytic Spitz nevus, pediatric astrocytoma, a subset of thyroid papillary carcinoma, leukemia, NTRK-rearranged mesenchymal spindle cell tumors, and inflammatory myofibroblastic tumors [126,128-145]. 
a
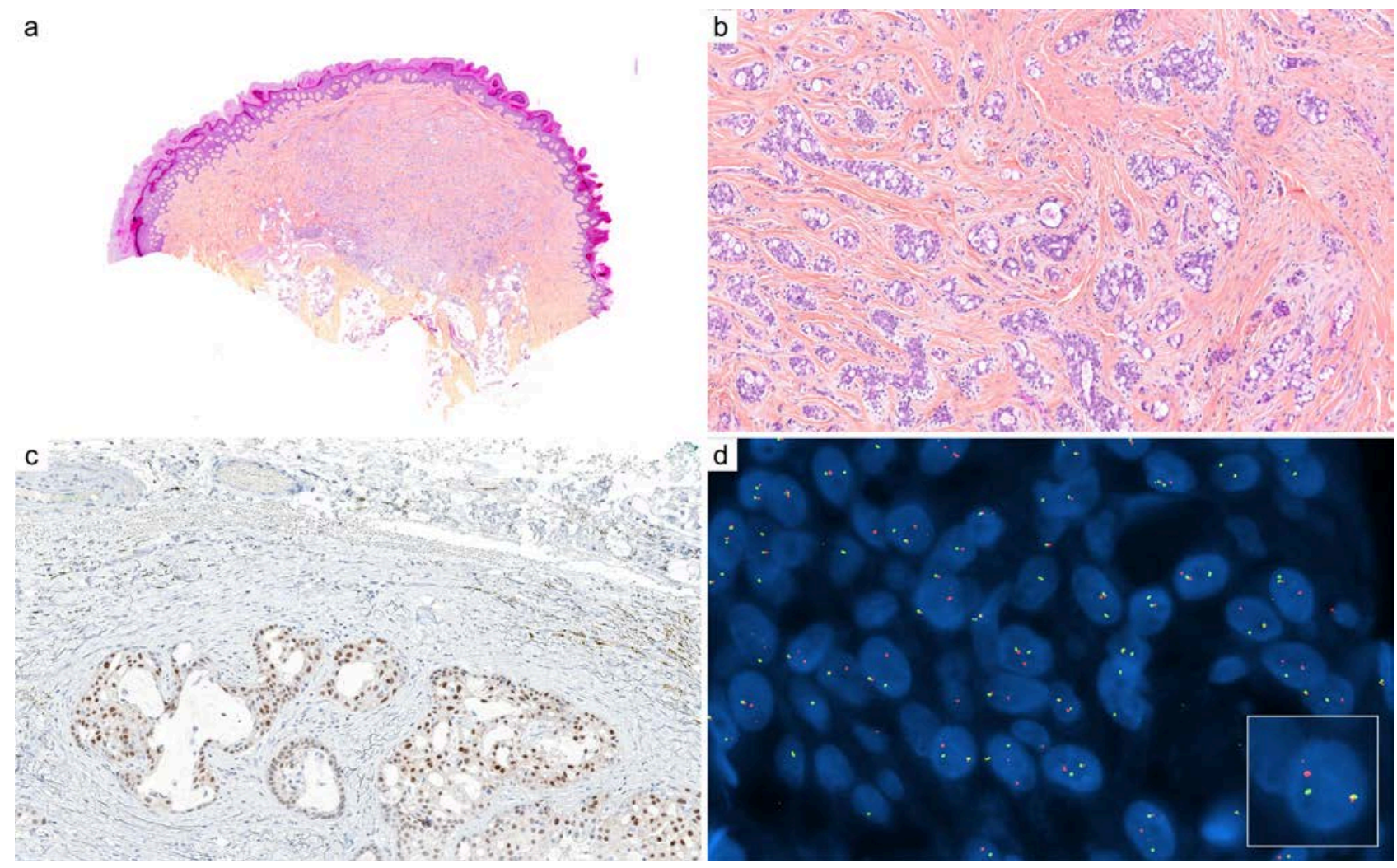

Figure 7. Cutaneous secretory carcinoma: (a) circumscribed intradermal neoplastic proliferation $(\times 10)$; (b) intracytoplasmic secretory vacuoles and extracellular bubbly eosinophilic secretions $(\times 100)$; (c) nuclear staining with panTRK immunohistochemistry is highly suggestive of ETV6::NTRK3 fusion ( $\times 200)$; (d) fluorescence in situ hybridization (FISH, break-apart) demonstrates clonal and balanced rearrangement of NTRK3 gene $(\times 1000)$.

\subsection{Tubular Adenoma and Syringocystadenoma Papilliferum}

General features: Tubular adenoma and syringocystadenoma papilliferum (SCAP, Figure 8) are related entities with an epithelial myoepithelial phenotype and tubulopapillary architecture [146]. Both are related to activation of mutations in the mitogen-activated protein kinase (MAPK) signaling pathway, affecting BRAF, KRAS, and HRAS. Both tubular adenoma and syringocystadenoma papilliferum can develop sporadically or more frequently on the genetic background of a cutaneous mosaic RASopathy, such as nevus sebaceus of Jadassohn $[147,148]$.

Related terminology: The salivary and bronchus homologous neoplasm is called sialadenoma papilliferum.

Immunohistochemistry: Immunostains can be used successfully to detect cases with BRAF p.V600E mutation, with excellent sensitivity and specificity with the anti-BRAF p.V600E antibody (clone VE1) [149]. Epithelial myoepithelial differentiation of SCAP and tubular adenoma can be revealed by a panel including SMA, calponin, SOX10, and p63 to highlight the outer myoepithelial layer and luminal cytokeratins and EMA for the inner layer. Most cases are associated with plasma cells within the papillary axis, which can be stained with MUM1 and CD138. 


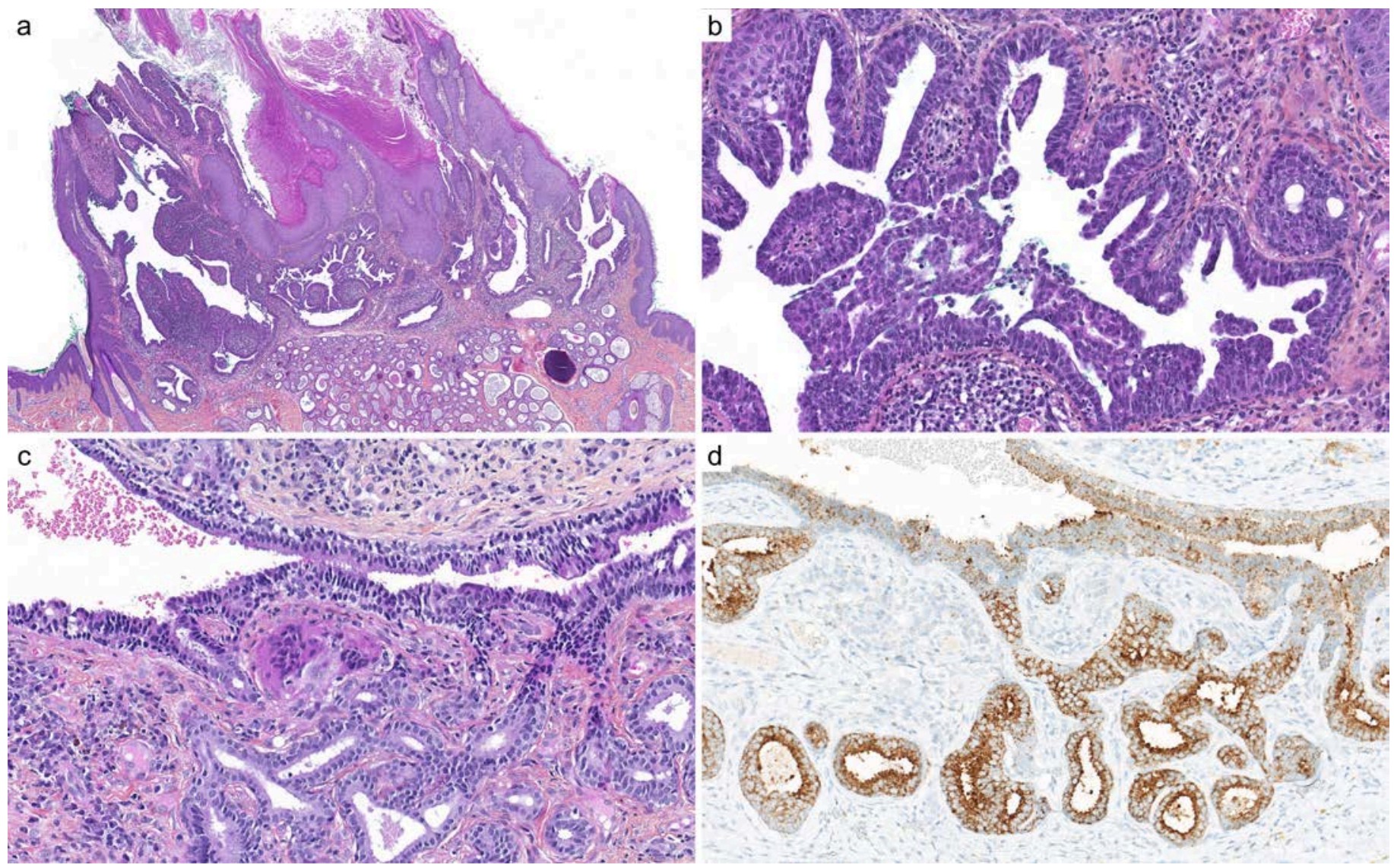

Figure 8. Syringocystadenoma papilliferum and tubular adenoma: (a) hybrid lesion with superficial syringocystadenoma papilliferum and dermal tubular adenoma arising on a nevus sebaceous, with verrucous change $(\times 10)$; (b) syringocystadenoma papilliferum shows papillary projections, epithelial and myoepithelial cells, and numerous plasma cells in the adjacent dermis $(\times 100)$; (c) tubular adenoma exhibits numerous ducts, tubes, and cysts with apocrine decapitation $(\times 200)$; (d) BRAF p.V600E (clone VE1) immunohistochemistry intensely and diffusely stains the cytoplasm of neoplastic cells $(\times 200)$.

Molecular biology: BRAF p.V600E mutations are detected in 50-64\% of syringocystadenomas papilliferum and $66 \%$ of tubular adenomas, respectively. Tumors that arise in nevus sebaceus almost constantly harbor HRAS or KRAS mutations [150]. Activating mutations of $B R A F, H R A S$, and KRAS increase cell growth, differentiation, and survival. In sporadic tumors, $H R A S$ p.G13R mutations are found in $7-26 \%$ of cases, while $K R A S$ p.G12D mutations are less frequent [151,152]. DNA of HPV type 16 and 68 have been detected in SCAP of the perianal area and buttock, without HPV-related morphology [153]. Verrucous proliferations associated with SCAP demonstrate BRAF mutation in both the glandular and contiguous hyperplastic squamous epithelium [149,154,155]. Sialadenoma papilliferum exhibits the same morphology and carries $B R A F$ p.V600E mutation in most cases, while reports of $R A S$ mutations are currently lacking [156,157]. No data have been published on malignant SCAP, but various mutations have been reported in a case report of metastatic adenocarcinoma with papillary architecture, presumably originating from a SCAP that included ARID2, CDKN2A, ERBB4, FAT1, FGF10, FGFR1, GNA11, KDM5C, MAGI2, NFKBIA, NOTCH1, PIK3CA, RAC1, RICTOR, SLIT2, TERT, TP53 mutations. More studies are needed to discover the molecular landscape of the malignant counterpart of SCAP. A case of digital papillary adenocarcinoma with BRAF p.V600E has been published but could represent a malignant form of tubular adenoma [158]. In this context, inhibitors of BRAF could be employed. 


\subsection{Endocrine Mucin-Producing Sweat Gland Carcinoma}

General features: Endocrine mucin-producing sweat gland carcinoma (EMPSGC, Figure 9) is a low-grade mucin-producing sweat gland carcinoma with a neuroendocrine phenotype and a predilection for the eyelids and periorbital skin [159,160].
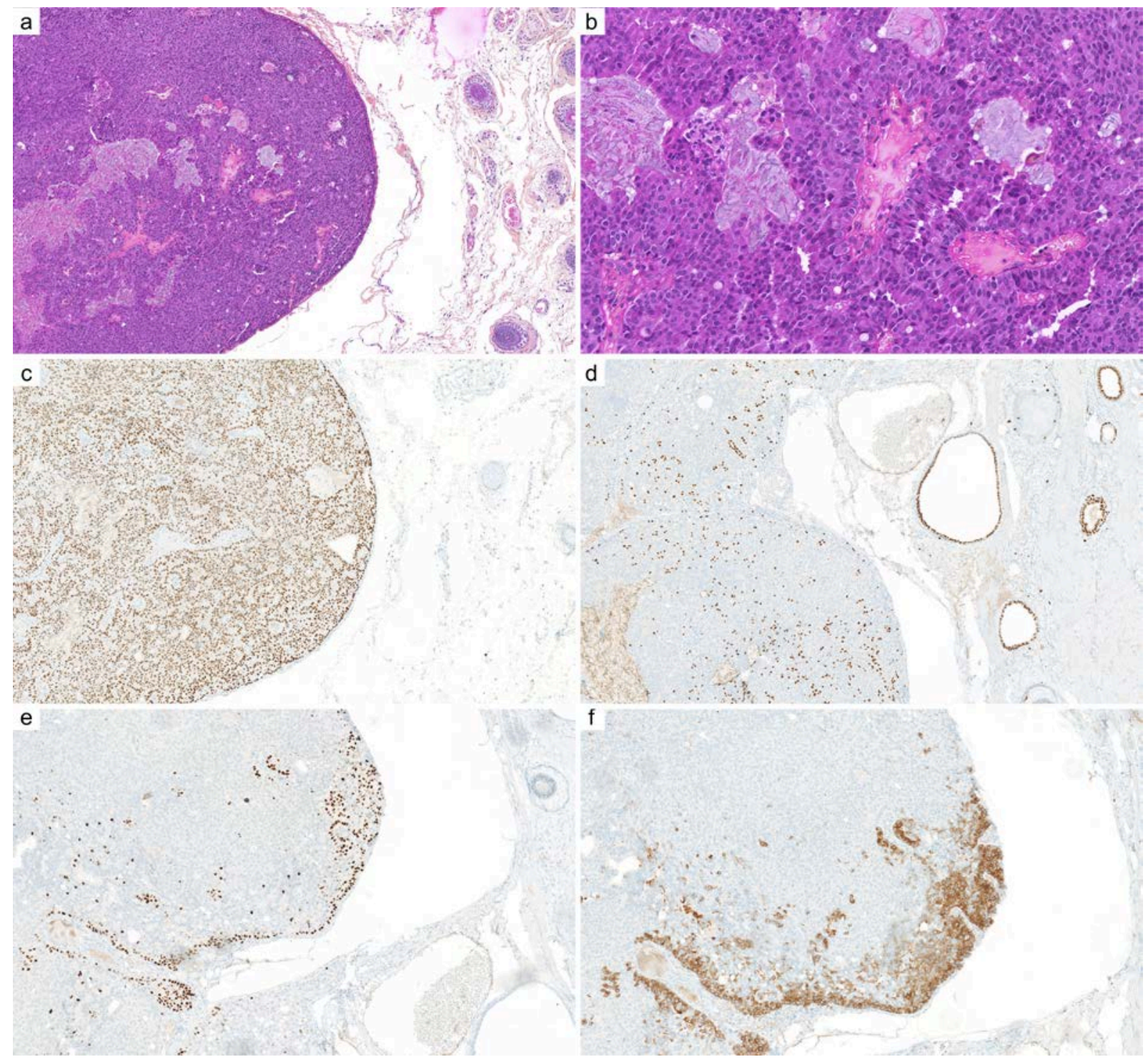

Figure 9. Histopathological findings immunohistochemistry of endocrine mucin-producing sweat gland carcinoma: (a) EMPSGC exhibits a well-circumscribed, nodular, sometimes cystic architecture $(\times 100)$; (b) variable amount of intra- and extracellular mucin is present $(\times 200)$; (c) immunohistochemistry for androgen receptor (AR) exhibits diffuse nuclear expression $(\times 100)$; (d) SOX10 stains a variable proportion of cells $(\times 100)$; the expression of neuroendocrine markers varies: INSM1 $(\times 100)$ (e) and synaptophysin $(\times 100)(\mathbf{f})$.

Related terminology: The related homologous neoplasm is called solid papillary adenocarcinoma of the breast. Endocrine mucin-producing sweat gland carcinoma may represent a precursor of mucinous sweat gland carcinoma (neuroendocrine type) [159,160]. Low-grade neuroendocrine carcinoma of the skin/primary cutaneous carcinoid tumors might represent a variant or a closely related entity [161].

Immunohistochemistry: Endocrine mucin-producing sweat gland carcinoma (EMPSGC) expresses INSM1, synaptophysin (90\%), chromogranin (71\%), ER (98\%), PR (96\%), and AR $[18,162]$. Other positive stains include CK7, CK8, CK18, EMA, GCDFP15, WT1, Bcl2, 
MUC2, MUC4, RB1, SOX10, and MYB. Identification of a preserved myoepithelial layer expressing p63 supports the diagnosis $[159,160,163-166]$.

Molecular biology: Identified mutations affect genes involved in DNA damage response/repair (BRD4, PPP4R2, and RTEL1), regulation of transcription/post transcriptional processing (BRD4, RBM10, ZFHX3, and SMYD3), and tumor suppressors (BRD4, TP53, TSC1, and LATS2) [167]. Other studies have not demonstrated relevant molecular drivers $[164,168,169]$.

\section{Main Clinical Settings to Use These Biomarkers and Their Limits}

Although some of these biomarkers are directly linked to a specific diagnosis, other markers are associated with a whole spectrum. In fact, demonstrating a rearrangement of MYB, MYBL1, PLAG1, HMGA2, NTRK3, and a BRAF mutation in the appropriate morphological context is diagnostic of adenoid cystic carcinoma, cutaneous mixed tumor, secretory carcinoma, syringocystadenoma papilliferum, and tubular adenoma. On the other hand, the demonstration of fusion of YAP1, NUTM1, MAML2, EWSR1, FUS, and mutation of CYLD and ALPK1 points to the poroid, hidradenomatous, myoepithelial, cylindromatous, and spiradenomatous categories of tumors, and these alterations do not predict prognosis or malignancy, which is based on other characteristics, such as morphology and proliferation. Other alterations are used for diagnostic and theranostic purposes, such as the BRAF p.V600E mutation and the fusion of NTRK3.

Some cases still lack any detectable molecular or immunohistochemical hallmark, and there is not a single answer to this question: variation in the sensitivity of the molecular techniques used, unreported gene fusion, alternative molecular mechanisms, and misinterpretation of pathological findings may contribute to the variation in prevalence of observed anomalies. The exact prevalence of these molecular anomalies is still unknown given the lack of data and large studies that include bona fide cases.

\section{Other Sweat Gland Tumors Lacking Recent Data}

Numerous other sweat gland tumors and related carcinomas still lack extensive molecular or immunohistochemical data, notably histiocytoid carcinoma, papillary digital adenocarcinoma, polymorphous sweat gland carcinoma, squamoid eccrine ductal carcinoma, mucinous carcinoma, apocrine carcinoma, and adnexal adenocarcinomas without other specification (NOS). This lack of data is the consequence of the combination of their rarity and diversity, which prevents large-scale studies from focusing on their molecular background. Networks of pathologists with common and robust diagnostic criteria, collaborative work, and collections of these rare neoplasms are of utmost importance to improve their diagnosis and allow proper future research $[1,170,171]$.

\section{Conclusions}

The molecular landscape of cutaneous adnexal tumors has changed dramatically in the past few years. The addition of robust biomarkers in an integrated molecular-pathological approach is more likely to positively impact the reproducibility of diagnoses. Due to their great variety, rarity, complex terminology, and overlapping microscopic and phenotypic features, the pathological diagnosis of rare cutaneous neoplasms is challenging. However, these novel molecular and immunohistochemical hallmarks are expected to improve overall diagnostic accuracy due to their high specificity when integrated into an appropriate clinical and pathological context. Ultimately, since the entities will be systematically validated with a specific hallmark, standardized diagnoses will pave the way for future studies investigating the prognosis and therapeutic management of these rare cutaneous tumors.

Author Contributions: Writing—original draft preparation, N.M.; writing-review and editing, N.M., T.K., P.S., D.P., M.-L.J. and M.B.; FISH analyses, D.P.; supervision, B.C. and M.B. All authors have read and agreed to the published version of the manuscript.

Funding: This research received no external funding. 
Conflicts of Interest: The authors declare no conflict of interest.

\section{References}

1. Seris, A.; Battistella, M.; Beylot-Barry, M.; Dalle, S.; Mortier, L.; Lebbé, C.; Blom, A.; Neidhart-Berard, E.-M.; Kramkimel, N.; Dupuy, A.; et al. Creation, implementation and objectives of CARADERM, a national network for rare skin carcinomas-Adnexal neoplasm part. Ann. Dermatol. Venereol. 2019, 146, 704-710. [CrossRef] [PubMed]

2. Elder, D.E.; Massi, D.; Scolyer, R.A.; Willemze, R. WHO Classification of Skin Tumours; International Agency for Research on Cancer: Lyon, France, 2018; ISBN 978-92-832-2440-2.

3. Pickering, C.R.; Zhou, J.H.; Lee, J.J.; Drummond, J.A.; Peng, S.A.; Saade, R.E.; Tsai, K.Y.; Curry, J.L.; Tetzlaff, M.T.; Lai, S.Y.; et al. Mutational landscape of aggressive cutaneous squamous cell carcinoma. Clin. Cancer. Res. 2014, 20, 6582-6592. [CrossRef]

4. Bonilla, X.; Parmentier, L.; King, B.; Bezrukov, F.; Kaya, G.; Zoete, V.; Seplyarskiy, V.B.; Sharpe, H.J.; McKee, T.; Letourneau, A.; et al. Genomic analysis identifies new drivers and progression pathways in skin basal cell carcinoma. Nat Genet. 2016, 48, 398-406. [CrossRef] [PubMed]

5. $\quad$ Brill, L.B.; Kanner, W.A.; Fehr, A.; Andrén, Y.; Moskaluk, C.A.; Löning, T.; Stenman, G.; Frierson, H.F. Analysis of MYB expression and MYB-NFIB gene fusions in adenoid cystic carcinoma and other salivary neoplasms. Mod. Pathol. 2011, 24, 1169-1176. [CrossRef]

6. Mitani, Y.; Rao, P.H.; Futreal, P.A.; Roberts, D.B.; Stephens, P.J.; Zhao, Y.-J.; Zhang, L.; Mitani, M.; Weber, R.S.; Lippman, S.M.; et al. Novel chromosomal rearrangements and break points at the $t(6 ; 9)$ in salivary adenoid cystic carcinoma: Association with MYB-NFIB chimeric fusion, MYB expression, and clinical outcome. Clin. Cancer Res. 2011, 17, 7003-7014. [CrossRef]

7. Stenman, G.; Persson, F.; Andersson, M.K. Diagnostic and therapeutic implications of new molecular biomarkers in salivary gland cancers. Oral. Oncol. 2014, 50, 683-690. [CrossRef]

8. Hsieh, M.-S.; Lee, Y.-H.; Chang, Y.-L. SOX10-Positive salivary gland tumors: A growing list, including mammary analogue secretory carcinoma of the salivary gland, sialoblastoma, low-grade salivary duct carcinoma, basal cell adenoma/adenocarcinoma, and a subgroup of mucoepidermoid carcinoma. Hum. Pathol. 2016, 56, 134-142. [CrossRef] [PubMed]

9. $\quad$ Lee, J.H.; Kang, H.J.; Yoo, C.W.; Park, W.S.; Ryu, J.S.; Jung, Y.-S.; Choi, S.W.; Park, J.Y.; Han, N. PLAG1, SOX10, and myb expression in benign and malignant salivary gland neoplasms. J. Pathol. Transl. Med. 2019, 53, 23-30. [CrossRef] [PubMed]

10. Yang, C.; Zhang, L.; Sanati, S. SOX10 is a sensitive marker for breast and salivary gland adenoid cystic carcinoma: Immunohistochemical characterization of adenoid cystic carcinomas. Breast Cancer 2019, 13, 1178223419842185. [CrossRef]

11. Adkins, B.D.; Geromes, A.; Zhang, L.Y.; Chernock, R.; Kimmelshue, K.; Lewis, J.; Ely, K. SOX10 and GATA3 in adenoid cystic carcinoma and polymorphous adenocarcinoma. Head Neck Pathol. 2020, 14, 406-411. [CrossRef]

12. Prieto-Granada, C.N.; Zhang, L.; Antonescu, C.R.; Henneberry, J.M.; Messina, J.L. Primary cutaneous adenoid cystic carcinoma with MYB aberrations: Report of three cases and comprehensive review of the literature. J. Cutan. Pathol. 2017, 44, 201-209. [CrossRef]

13. Andreadis, D.; Epivatianos, A.; Poulopoulos, A.; Nomikos, A.; Papazoglou, G.; Antoniades, D.; Barbatis, C. Detection of C-KIT (CD117) molecule in benign and malignant salivary gland tumours. Oral Oncol. 2006, 42, 57-65. [CrossRef] [PubMed]

14. Pardal, J.; Sundram, U.; Selim, M.A.; Hoang, M.P. GATA3 and MYB Expression in cutaneous adnexal neoplasms. Am. J. Derm. 2017, 39, 279-286. [CrossRef] [PubMed]

15. Wood, A.; Houghton, S.L.; Biswas, A. A Comparative study of immunohistochemical myoepithelial cell markers in cutaneous benign cystic apocrine lesions. Am. J. Derm. 2016, 38, 475-483. [CrossRef]

16. North, J.P.; McCalmont, T.H.; Fehr, A.; van Zante, A.; Stenman, G.; LeBoit, P.E. Detection of MYB Alterations and other immunohistochemical markers in primary cutaneous adenoid cystic carcinoma. Am. J. Surg. Pathol. 2015, 39, 1347-1356. [CrossRef] [PubMed]

17. Ramakrishnan, R.; Chaudhry, I.H.; Ramdial, P.; Lazar, A.J.; McMenamin, M.E.; Kazakov, D.; Brenn, T.; Calonje, E. Primary cutaneous adenoid cystic carcinoma: A clinicopathologic and immunohistochemical study of 27 cases. Am. J. Surg. Pathol. 2013, 37, 1603-1611. [CrossRef] [PubMed]

18. Evangelista, M.T.P.; North, J.P. MYB, CD117 and SOX-10 expression in cutaneous adnexal tumors. J. Cutan. Pathol. 2017, 44, 444-450. [CrossRef]

19. West, R.B.; Kong, C.; Clarke, N.; Gilks, T.; Lipsick, J.S.; Cao, H.; Kwok, S.; Montgomery, K.D.; Varma, S.; Le, Q.-T. MYB Expression and translocation in adenoid cystic carcinomas and other salivary gland tumors with clinicopathologic correlation. Am. J. Surg. Pathol. 2011, 35, 92-99. [CrossRef] [PubMed]

20. McIntyre, J.B.; Ko, J.J.; Siever, J.; Chan, A.M.Y.; Simpson, R.H.W.; Hao, D.; Lau, H.Y. MYB-NFIB Gene fusions identified in archival adenoid cystic carcinoma tissue employing nanostring analysis: An exploratory study. Diagn. Pathol. 2019, 14, 78. [CrossRef]

21. Lv, J.-J.; Ren, M.; Cai, X.; Hu, J.; Kong, J.-C.; Kong, Y.-Y. Primary cutaneous adenoid cystic carcinoma: A clinicopathologic, immunohistochemical, and fluorescence in-situ hybridisation study of 13 cases. Histopathology 2021, 80, 407-419. [CrossRef]

22. Goto, K.; Kajimoto, K.; Sugino, T.; Nakatsuka, S.-I.; Yoshida, M.; Noto, M.; Kono, M.; Takai, T. MYB Translocations in both myoepithelial and ductoglandular epithelial cells in adenoid cystic carcinoma: A histopathologic and genetic reappraisal in six primary cutaneous cases. Am. J. Derm. 2021, 43, 278-283. [CrossRef] [PubMed] 
23. Togashi, Y.; Dobashi, A.; Sakata, S.; Sato, Y.; Baba, S.; Seto, A.; Mitani, H.; Kawabata, K.; Takeuchi, K. MYB and MYBL1 in adenoid cystic carcinoma: Diversity in the mode of genomic rearrangement and transcripts. Mod. Pathol. 2018, 31, 934-946. [CrossRef] [PubMed]

24. Kyrpychova, L.; Vanecek, T.; Grossmann, P.; Martinek, P.; Steiner, P.; Hadravsky, L.; Belousova, I.E.; Shelekhova, K.V.; Svajdler, M.; Dubinsky, P.; et al. Small subset of adenoid cystic carcinoma of the skin is associated with alterations of the MYBL1 gene similar to their extracutaneous counterparts. Am. J. Derm. 2018, 40, 721-726. [CrossRef]

25. Kim, J.; Geyer, F.C.; Martelotto, L.G.; Ng, C.K.; Lim, R.S.; Selenica, P.; Li, A.; Pareja, F.; Fusco, N.; Edelweiss, M.; et al. MYBL1 rearrangements and MYB amplification in breast adenoid cystic carcinomas lacking the MYB-NFIB fusion gene. J. Pathol. 2018, 244, 143-150. [CrossRef]

26. George, O.L.; Ness, S.A. Situational awareness: Regulation of the myb transcription factor in differentiation, the cell cycle and oncogenesis. Cancers 2014, 6, 2049-2071. [CrossRef] [PubMed]

27. Di Villeneuve, L.; Souza, I.L.; Tolentino, F.D.S.; Ferrarotto, R.; Schvartsman, G. Salivary gland carcinoma: Novel targets to overcome treatment resistance in advanced disease. Front. Oncol. 2020, 10, 580141. [CrossRef] [PubMed]

28. Fehr, A.; Kovács, A.; Löning, T.; Frierson, H.; Van den Oord, J.; Stenman, G. The MYB-NFIB gene fusion-A novel genetic link between adenoid cystic carcinoma and dermal cylindroma. J. Pathol. 2011, 224, 322-327. [CrossRef]

29. Rashid, M.; van der Horst, M.; Mentzel, T.; Butera, F.; Ferreira, I.; Pance, A.; Rütten, A.; Luzar, B.; Marusic, Z.; de Saint Aubain, N.; et al. ALPK1 hotspot mutation as a driver of human spiradenoma and spiradenocarcinoma. Nat. Commun. 2019, 10, 2213. [CrossRef]

30. Russell-Goldman, E.; Dubuc, A.; Hanna, J. Differential expression of PLAG1 in apocrine and eccrine cutaneous mixed tumors: Evidence for distinct molecular pathogenesis. Am. J. Derm. 2020, 42, 251-257. [CrossRef]

31. Panagopoulos, I.; Gorunova, L.; Andersen, K.; Lund-Iversen, M.; Lobmaier, I.; Micci, F.; Heim, S. NDRG1-PLAG1 and TRPS1PLAG1 fusion genes in chondroid syringoma. Cancer Genom. Proteom. 2020, 17, 237-248. [CrossRef]

32. Matsuyama, A.; Hisaoka, M.; Hashimoto, H. PLAG1 Expression in Mesenchymal Tumors: An Immunohistochemical Study with Special Emphasis on the Pathogenetical Distinction between Soft Tissue Myoepithelioma and Pleomorphic Adenoma of the Salivary Gland. Pathol. Int. 2012, 62, 1-7. [CrossRef]

33. Katabi, N.; Ghossein, R.; Ho, A.; Dogan, S.; Zhang, L.; Sung, Y.-S.; Antonescu, C.R. Consistent PLAG1 and HMGA2 abnormalities distinguish carcinoma ex-pleomorphic adenoma from its de novo counterparts. Hum. Pathol. 2015, 46, 26-33. [CrossRef]

34. Stenman, G. Fusion oncogenes and tumor type specificity-Insights from salivary gland tumors. Semin. Cancer Biol. 2005, 15, 224-235. [CrossRef] [PubMed]

35. Stenman, G. Fusion Oncogenes in salivary gland tumors: Molecular and clinical consequences. Head Neck Pathol. 2013, 7 (Suppl. 1), S12-S19. [CrossRef]

36. Matsuyama, A.; Hisaoka, M.; Hashimoto, H. PLAG1 Expression in cutaneous mixed tumors: An immunohistochemical and molecular genetic study. Virchows Arch. 2011, 459, 539-545. [CrossRef] [PubMed]

37. Panagopoulos, I.; Gorunova, L.; Lund-Iversen, M.; Bassarova, A.; Heim, S. Fusion of the genes PHF1 and TFE3 in malignant chondroid syringoma. Cancer Genom. Proteom. 2019, 16, 345-351. [CrossRef] [PubMed]

38. Iida, K.; Iwai, S.; Hosaka, H.; Kitami, Y.; Akiyama, M.; Suzuki, T.; Sueki, H. Immunohistochemical characterization of nonepithelial cells in spiradenoma. J. Derm. 2013, 40, 896-900. [CrossRef]

39. Yiğit, N.; Çelik, E.; Yavan, İ.; Günal, A.; Kurt, B.; Karslığlu, Y.; Öngürü, Ö.; Özcan, A. Distinctive immunostaining of claudin-4 in spiradenomas. Ann. Diagn. Pathol. 2016, 20, 44-47. [CrossRef]

40. Petersson, F.; Nga, M.E. Spiradenocarcinoma with low-grade basal cell adenocarcinoma pattern: Report of a Case with varied morphology and wild type TP53. J. Cutan. Pathol. 2012, 39, 372-376. [CrossRef]

41. Van der Horst, M.P.J.; Marusic, Z.; Hornick, J.L.; Luzar, B.; Brenn, T. Morphologically low-grade spiradenocarcinoma: A Clinicopathologic study of 19 cases with emphasis on outcome and myb expression. Mod. Pathol. 2015, 28, 944-953. [CrossRef]

42. Bignell, G.R.; Warren, W.; Seal, S.; Takahashi, M.; Rapley, E.; Barfoot, R.; Green, H.; Brown, C.; Biggs, P.J.; Lakhani, S.R.; et al. Identification of the familial cylindromatosis tumour-suppressor gene. Nat. Genet. 2000, 25, 160-165. [CrossRef] [PubMed]

43. Biernat, W.; Peraud, A.; Wozniak, L.; Ohgaki, H. P53 Mutations in sweat gland carcinomas. Int. J. Cancer 1998, 76, 317-320. [CrossRef]

44. Rajan, N.; Andersson, M.K.; Sinclair, N.; Fehr, A.; Hodgson, K.; Lord, C.J.; Kazakov, D.V.; Vanecek, T.; Ashworth, A.; Stenman, G. Overexpression of MYB drives proliferation of CYLD-defective cylindroma cells. J. Pathol. 2016, 239, 197-205. [CrossRef]

45. Williams, E.A.; Montesion, M.; Sharaf, R.; Corines, J.; Patel, P.J.; Gillespie, B.J.; Pavlick, D.C.; Sokol, E.S.; Alexander, B.M.; Williams, K.J.; et al. CYLD-mutant cylindroma-like basaloid carcinoma of the anus: A Genetically and morphologically distinct class of HPV-related anal carcinoma. Mod. Pathol. 2020, 33, 2614-2625. [CrossRef]

46. Williams, E.A.; Montesion, M.; Alexander, B.M.; Ramkissoon, S.H.; Elvin, J.A.; Ross, J.S.; Williams, K.J.; Glomski, K.; Bledsoe, J.R.; Tse, J.Y.; et al. CYLD Mutation characterizes a subset of HPV-positive head and neck squamous cell carcinomas with distinctive genomics and frequent cylindroma-like histologic features. Mod. Pathol. 2021, 34, 358-370. [CrossRef] [PubMed]

47. Wiedemeyer, K.; Gill, P.; Schneider, M.; Kind, P.; Brenn, T. Clinicopathologic characterization of hidradenoma on acral sites: A Diagnostic pitfall with digital papillary adenocarcinoma. Am. J. Surg. Pathol. 2019, 44, 711-717. [CrossRef]

48. Cassarino, D.S.; Su, A.; Robbins, B.A.; Altree-Tacha, D.; Ra, S. SOX10 Immunohistochemistry in sweat ductal/glandular neoplasms. J. Cutan. Pathol. 2017, 44, 544-547. [CrossRef] 
49. Nazarian, R.M.; Kapur, P.; Rakheja, D.; Piris, A.; Duncan, L.M.; Mihm, M.C.; Hoang, M.P. Atypical and malignant hidradenomas: A histological and immunohistochemical study. Mod. Pathol. 2009, 22, 600-610. [CrossRef]

50. Yoshimi, K.; Goto, H.; Otsuka, M.; Yoshikawa, S.; Omodaka, T.; Kiyohara, Y. Translocation of the MAML2 gene in hidradenocarcinoma. J. Derm. 2017, 44, e190-e191. [CrossRef]

51. Seethala, R.R.; Dacic, S.; Cieply, K.; Kelly, L.M.; Nikiforova, M.N. A Reappraisal of the MECT1/MAML2 Translocation in salivary mucoepidermoid carcinomas. Am. J. Surg. Pathol. 2010, 34, 1106-1121. [CrossRef]

52. Jee, K.J.; Persson, M.; Heikinheimo, K.; Passador-Santos, F.; Aro, K.; Knuutila, S.; Odell, E.W.; Mäkitie, A.; Sundelin, K.; Stenman, G.; et al. Genomic Profiles and CRTC1-MAML2 Fusion distinguish different subtypes of mucoepidermoid carcinoma. Mod. Pathol. 2013, 26, 213-222. [CrossRef]

53. Nakayama, T.; Miyabe, S.; Okabe, M.; Sakuma, H.; Ijichi, K.; Hasegawa, Y.; Nagatsuka, H.; Shimozato, K.; Inagaki, H. Clinicopathological significance of the CRTC3-MAML2 fusion transcript in mucoepidermoid carcinoma. Mod. Pathol. 2009, 22, 1575-1581. [CrossRef] [PubMed]

54. Kazakov, D.V.; Ivan, D.; Kutzner, H.; Spagnolo, D.V.; Grossmann, P.; Vanecek, T.; Sima, R.; Kacerovska, D.; Shelekhova, K.V.; Denisjuk, N.; et al. Cutaneous hidradenocarcinoma: A clinicopathological, immunohistochemical, and molecular biologic study of 14 Cases, including Her2/Neu gene expression/amplification, TP53 gene mutation analysis, and t(11;19) translocation. Am. J. Derm. 2009, 31, 236-247. [CrossRef] [PubMed]

55. Kyrpychova, L.; Kacerovska, D.; Vanecek, T.; Grossmann, P.; Michal, M.; Kerl, K.; Kazakov, D.V. Cutaneous Hidradenoma: A study of 21 neoplasms revealing neither correlation between the cellular composition and CRTC1-MAML2 fusions nor presence of CRTC3-MAML2 fusions. Ann. Diagn. Pathol. 2016, 23, 8-13. [CrossRef]

56. Yan, K.; Yesensky, J.; Hasina, R.; Agrawal, N. Genomics of mucoepidermoid and adenoid cystic carcinomas. Laryngoscope Investig. Otolaryngol. 2018, 3, 56-61. [CrossRef]

57. Wu, Y.; He, Z.; Li, S.; Tang, H.; Wang, L.; Yang, S.; Dong, B.; Qin, J.; Sun, Y.; Yu, H.; et al. Gefitinib represses JAK-STAT signaling activated by CRTC1-MAML2 fusion in mucoepidermoid carcinoma cells. Curr. Cancer Drug Targets 2019, 19, 796-806. [CrossRef]

58. Möller, E.; Stenman, G.; Mandahl, N.; Hamberg, H.; Mölne, L.; van den Oord, J.J.; Brosjö, O.; Mertens, F.; Panagopoulos, I POU5F1, encoding a key regulator of stem cell pluripotency, is fused to EWSR1 in Hidradenoma of the skin and mucoepidermoid carcinoma of the salivary glands. J. Pathol. 2008, 215, 78-86. [CrossRef] [PubMed]

59. Bozdogan, O.; Kadan, E.; Bozdogan, N. Are there EWSR1 rearranged cutaneous hidradenomas and mucoepidermoid carcinomas of salivary glands? A fish study and review of the literature. Pol. J. Pathol. 2020, 71, 99-106. [CrossRef]

60. Antonescu, C.R.; Zhang, L.; Chang, N.-E.; Pawel, B.R.; Travis, W.; Katabi, N.; Edelman, M.; Rosenberg, A.E.; Nielsen, G.P.; Dal Cin, P.; et al. EWSR1-POU5F1 fusion in soft tissue myoepithelial tumors. A molecular analysis of sixty-six cases, including soft tissue, bone, and visceral lesions, showing common involvement of the EWSR1 gene. Genes Chromosomes Cancer 2010, 49, 1114-1124. [CrossRef]

61. Llamas-Velasco, M.; Pérez-Gónzalez, Y.C.; Bosch-Príncep, R.; Fernández-Figueras, M.-T.; Rütten, A. Solid Carcinoma Is a Variant of microcystic adnexal carcinoma: A 14-case series. J. Cutan. Pathol. 2018, 45, 897-904. [CrossRef]

62. Torre-Castro, J.; Moya-Martinez, C.; Sangueza, O.; Raquena, L. Microcystic Adnexal Adenoma: The Benign Counterpart of Microcystic Adnexal Carcinoma. Am. J. Dermatopathol. 2021, 43. [CrossRef] [PubMed]

63. Mentzel, J.; Wetzig, T.; Rutten, A.; Hortnagel, K.; Tischkowitz, M.; Ziemer, M. Sweat Duct Proliferation Associated with Aggregation of Elastic Tissue and Atrophodermia Vermiculata: A Simulator of Microcystic Adnexal Carcinoma-A Family with MALTA-Syndrome. J. Der Dtsch. Dermatol. Gesellschaft. J. Ger. Soc. Dermatol. 2021, 19, 1052-1056. [CrossRef] [PubMed]

64. Hoang, M.P.; Dresser, K.A.; Kapur, P.; High, W.A.; Mahalingam, M. Microcystic adnexal carcinoma: An immunohistochemical reappraisal. Mod. Pathol. 2008, 21, 178-185. [CrossRef]

65. Sellheyer, K.; Nelson, P.; Kutzner, H.; Patel, R.M. The immunohistochemical differential diagnosis of microcystic adnexal carcinoma, desmoplastic trichoepithelioma and morpheaform basal cell carcinoma using BerEP4 and stem cell markers: BerEP4 and stem cell markers in adnexal neoplasms. J. Cutan. Pathol. 2013, 40, 363-370. [CrossRef]

66. Gill, P.; Naugler, C.; Abi Daoud, M.S. Utility of Ber-EP4 and MOC-31 in basaloid skin tumor detection. Appl. Immunohistochem. Mol. Morphol. 2019, 27, 584-588. [CrossRef] [PubMed]

67. Krahl, D.; Sellheyer, K. Monoclonal Antibody Ber-EP4 Reliably discriminates between microcystic adnexal carcinoma and basal cell carcinoma. J Cutan. Pathol. 2007, 34, 782-787. [CrossRef] [PubMed]

68. Frouin, E.; Vignon-Pennamen, M.D.; Balme, B.; Cavelier-Balloy, B.; Zimmermann, U.; Ortonne, N.; Carlotti, A.; Pinquier, L.; André, J.; Cribier, B. Anatomoclinical Study of 30 cases of sclerosing sweat duct carcinomas (microcystic adnexal carcinoma, syringomatous carcinoma and squamoid eccrine ductal carcinoma). J. Eur. Acad. Derm. Venereol. 2015, 29, 1978-1994. [CrossRef]

69. Vidal, C.I.; Goldberg, M.; Burstein, D.E.; Emanuel, H.J.; Emanuel, P.O. P63 immunohistochemistry is a useful adjunct in distinguishing sclerosing cutaneous tumors. Am. J. Dermatopathol. 2010, 32, 257-261. [CrossRef]

70. Plaza, J.A.; Ortega, P.F.; Stockman, D.L.; Suster, S. Value of P63 and Podoplanin (D2-40) Immunoreactivity in the distinction between primary cutaneous tumors and adenocarcinomas metastatic to the skin: A clinicopathologic and immunohistochemical study of 79 cases. J. Cutan. Pathol. 2010, 37, 403-410. [CrossRef]

71. Smith, K.J.; Williams, J.; Corbett, D.; Skelton, H. Microcystic adnexal carcinoma: An immunohistochemical study including markers of proliferation and apoptosis. Am. J. Surg. Pathol. 2001, 25, 464-471. [CrossRef] 
72. Evangelista, M.T.P.; North, J.P. Comparative analysis of cytokeratin 15, TDAG51, cytokeratin 20 and androgen receptor in sclerosing adnexal neoplasms and variants of basal cell carcinoma: Comparative analysis of cytokeratin 15, TDAG51, cytokeratin 20 and androgen receptor. J. Cutan. Pathol. 2015, 42, 824-831. [CrossRef]

73. Bush, J.W.; Gru, A.A.; Wick, M.R. Immunoreactivity for Sox10 in basaloid neoplasms of the skin. Appl. Immunohistochem. Mol. Morphol. 2019, 27, 114-118. [CrossRef]

74. Chen, M.-B.; Laber, D.A. Metastatic microcystic adnexal carcinoma with DNA sequencing results and response to systemic antineoplastic chemotherapy. Anticancer. Res. 2017, 37, 5109-5111. [CrossRef]

75. Gambichler, T.; Hartenstein, I.; Dreißigacker, M.; Stockfleth, E.; Stücker, M.; Schaller, J.; Schulze, H.-J.; Becker, J.C.; Käfferlein, H.U.; Brüning, T.; et al. Expression of hedgehog signalling molecules in microcystic adnexal carcinoma. Clin. Exp. Derm. 2021, 46, 1052-1057. [CrossRef] [PubMed]

76. Suurmeijer, A.J.H.; Dickson, B.C.; Swanson, D.; Zhang, L.; Sung, Y.-S.; Fletcher, C.D.; Antonescu, C.R. A Morphologic and molecular reappraisal of myoepithelial tumors of soft tissue, bone, and viscera with EWSR1 and FUS gene rearrangements. Genes Chromosomes Cancer 2020, 59, 348-356. [CrossRef]

77. Michal, M.; Miettinen, M. Myoepitheliomas of the skin and soft tissues. Report of 12 Cases. Virchows Arch. 1999, 434, 393-400. [CrossRef] [PubMed]

78. Mentzel, T.; Requena, L.; Kaddu, S.; Soares de Aleida, L.M.; Sangueza, O.P.; Kutzner, H. Cutaneous myoepithelial neoplasms: Clinicopathologic and immunohistochemical study of 20 cases suggesting a continuous spectrum ranging from benign mixed tumor of the skin to cutaneous myoepithelioma and myoepithelial carcinoma. J. Cutan. Pathol. 2003, 30, 294-302. [CrossRef]

79. Hornick, J.L.; Fletcher, C.D.M. Cutaneous Myoepithelioma: A clinicopathologic and immunohistochemical study of 14 cases. Hum. Pathol. 2004, 35, 14-24. [CrossRef] [PubMed]

80. Jo, V.Y.; Antonescu, C.R.; Zhang, L.; Dal Cin, P.; Hornick, J.L.; Fletcher, C.D.M. Cutaneous syncytial myoepithelioma: Clinicopathologic characterization in a series of 38 cases. Am. J. Surg. Pathol. 2013, 37, 710-718. [CrossRef]

81. MacKinnon, W.F.; Carter, M.D.; Bridge, J.A.; Tremaine, R.D.; Walsh, N.M.G. EWSR1-PBX3 Gene fusion in cutaneous syncytial myoepithelioma. J. Cutan. Pathol. 2019, 46, 421-424. [CrossRef]

82. Jo, V.Y.; Antonescu, C.R.; Dickson, B.C.; Swanson, D.; Zhang, L.; Fletcher, C.D.M.; Demicco, E.G. Cutaneous syncytial myoepithelioma is characterized by recurrent EWSR1-PBX3 fusions. Am. J. Surg. Pathol. 2019, 43, 1349-1354. [CrossRef]

83. Komatsu, M.; Kawamoto, T.; Kanzawa, M.; Kawakami, Y.; Hara, H.; Akisue, T.; Kuroda, R.; Nakamura, H.; Hokka, D.; Jimbo, N.; et al. A novel EWSR1-VGLL1 gene fusion in a soft tissue malignant myoepithelial tumor. Genes Chromosomes Cancer 2020, 59, 249-254. [CrossRef]

84. Cajaiba, M.M.; Jennings, L.J.; Rohan, S.M.; Leuer, K.M.; Anagnost, M.R.; Fahner, J.B.; Fulton, B.K.; Geller, J.I.; Perlman, E.J. Expanding the spectrum of renal tumors in children: Primary renal myoepithelial carcinomas with a novel EWSR1-KLF15 fusion Am. J. Surg. Pathol. 2016, 40, 386-394. [CrossRef] [PubMed]

85. Wales, C.; Diamond, S.; Hinds, B. Cutaneous syncytial myoepithelioma: A nondescript skin tumor with serious diagnostic pitfalls. Int. J. Surg. Pathol. 2020, 28, 63-67. [CrossRef]

86. Huang, S.-C.; Chen, H.-W.; Zhang, L.; Sung, Y.-S.; Agaram, N.P.; Davis, M.; Edelman, M.; Fletcher, C.D.M.; Antonescu, C.R Novel FUS-KLF17 and EWSR1-KLF17 fusions in myoepithelial tumors. Genes Chromosomes Cancer 2015, 54, 267-275. [CrossRef] [PubMed]

87. Agaram, N.P.; Chen, H.-W.; Zhang, L.; Sung, Y.-S.; Panicek, D.; Healey, J.H.; Nielsen, G.P.; Fletcher, C.D.M.; Antonescu, C.R. EWSR1-PBX3: A novel gene fusion in myoepithelial tumors: A novel gene fusion in myoepithelial tumors. Genes Chromosomes Cancer 2015, 54, 63-71. [CrossRef]

88. Flucke, U.; Mentzel, T.; Verdijk, M.A.; Slootweg, P.J.; Creytens, D.H.; Suurmeijer, A.J.H.; Tops, B.B.J. EWSR1-ATF1 Chimeric transcript in a myoepithelial tumor of soft tissue: A case report. Hum. Pathol. 2012, 43, 764-768. [CrossRef] [PubMed]

89. Gleason, B.C.; Fletcher, C.D.M. Myoepithelial carcinoma of soft tissue in children: An aggressive neoplasm analyzed in a series of 29 cases. Am. J. Surg. Pathol. 2007, 31, 1813-1824. [CrossRef]

90. Hornick, J.L.; Dal Cin, P.; Fletcher, C.D.M. Loss of INI1 Expression is characteristic of both conventional and proximal-type epithelioid sarcoma. Am. J. Surg. Pathol. 2009, 33, 542-550. [CrossRef]

91. Le Loarer, F.; Zhang, L.; Fletcher, C.D.; Ribeiro, A.; Singer, S.; Italiano, A.; Neuville, A.; Houlier, A.; Chibon, F.; Coindre, J.-M.; et al. Consistent SMARCB1 homozygous deletions in epithelioid sarcoma and in a subset of myoepithelial carcinomas can be reliably detected by FISH in archival material. Genes Chromosomes Cancer 2014, 53, 475-486. [CrossRef]

92. Antonescu, C.R.; Zhang, L.; Shao, S.Y.; Mosquera, J.-M.; Weinreb, I.; Katabi, N.; Fletcher, C.D.M. Frequent PLAG1 gene rearrangements in skin and soft tissue myoepithelioma with ductal differentiation. Genes Chromosomes Cancer 2013, 52, 675-682. [CrossRef]

93. Requena, L.; Sánchez, M. Poroid hidradenoma: A light microscopic and immunohistochemical study. Cutis 1992, 50, 43-46. [PubMed]

94. Parra, O.; Kerr, D.A.; Bridge, J.A.; Loehrer, A.P.; Linos, K. A Case of YAP1 and NUTM1 Rearranged Porocarcinoma with corresponding immunohistochemical expression: Review of recent advances in poroma and porocarcinoma pathogenesis with potential diagnostic utility. J. Cutan. Pathol. 2021, 48, 95-101. [CrossRef] 
95. Macagno, N.; Kervarrec, T.; Sohier, P.; Poirot, B.; Haffner, A.; Carlotti, A.; Balme, B.; Castillo, C.; Jullie, M.-L.; Osio, A.; et al. NUT is a specific immunohistochemical marker for the diagnosis of YAP1-NUTM1-rearranged cutaneous poroid neoplasms. Am. J. Surg. Pathol. 2021, 45, 1221-1227. [CrossRef] [PubMed]

96. Russell-Goldman, E.; Hornick, J.L.; Hanna, J. Utility of YAP1 and NUT Immunohistochemistry in the diagnosis of porocarcinoma. J. Cutan. Pathol. 2020, 48, 403-410. [CrossRef] [PubMed]

97. Haack, H.; Johnson, L.A.; Fry, C.J.; Crosby, K.; Polakiewicz, R.D.; Stelow, E.B.; Hong, S.-M.; Schwartz, B.E.; Cameron, M.J.; Rubin, M.A.; et al. Diagnosis of NUT midline carcinoma using a NUT-specific monoclonal antibody. Am. J. Surg. Pathol. 2009, 33, 984-991. [CrossRef] [PubMed]

98. Kervarrec, T.; Amatore, F.; Pissaloux, D.; Paindavoine, S.; Legrand, E.; Lehmann-Che, J.; Battistella, M.; Macagno, N. Expanding the spectrum of primary cutaneous carcinoma with BRD3-NUTM1 fusion. Am. J. Surg. Pathol. 2021, 45, 1548-1586. [CrossRef]

99. Nishimura, Y.; Ryo, E.; Yamazaki, N.; Yatabe, Y.; Mori, T. Cutaneous primary NUT carcinoma with BRD3-NUTM1 fusion. Am. J. Surg. Pathol. 2021, 45, 1582-1584. [CrossRef] [PubMed]

100. Shen, J.; Pan, X.; Lu, Y.; Pan, D.; Ma, Y.; Zhan, R. A case of eccrine porocarcinoma characterized by a progressive increase in the level of Ki-67 index: Case report and review of literature. BMC Surg. 2019, 19, 142. [CrossRef]

101. Ansai, S.; Koseki, S.; Hozumi, Y.; Kondo, S. Assessment of cellular proliferation of eccrine acrospiromas and eccrine sweat gland carcinomas by AgNOR counting and immunohistochemical demonstration of proliferating cell nuclear antigen (PCNA) and Ki-67. Clin. Exp. Derm. 1995, 20, 27-34. [CrossRef]

102. Zahn, J.; Chan, M.P.; Wang, G.; Patel, R.M.; Andea, A.A.; Bresler, S.C.; Harms, P.W. Altered Rb, P16, and P53 Expression is specific for porocarcinoma relative to poroma. J. Cutan. Pathol. 2019, 46, 659-664. [CrossRef] [PubMed]

103. Goto, K.; Takai, T.; Fukumoto, T.; Anan, T.; Kimura, T.; Ansai, S.; Oshitani, Y.; Murata, Y.; Sakuma, T.; Hirose, T. CD117 (KIT) is a useful immunohistochemical marker for differentiating porocarcinoma from squamous cell carcinoma. J. Cutan. Pathol. 2016, 43, 219-226. [CrossRef]

104. Goto, K.; Ishikawa, M.; Hamada, K.; Muramatsu, K.; Naka, M.; Honma, K.; Sugino, T. Comparison of immunohistochemical expression of cytokeratin 19, c-KIT, BerEP4, GATA3, and NUTM1 between porocarcinoma and squamous cell carcinoma. Am. J. Derm. 2021, 43, 781-787. [CrossRef] [PubMed]

105. Nishioka, M.; Kunisada, M.; Fujiwara, N.; Oka, M.; Funasaka, Y.; Nishigori, C. Multiple apocrine poromas: A new case report. J. Cutan. Pathol. 2015, 42, 894-896. [CrossRef] [PubMed]

106. Yamamoto, O.; Hisaoka, M.; Yasuda, H.; Kasai, T.; Hashimoto, H. Cytokeratin expression of apocrine and eccrine poromas with special reference to its expression in cuticular cells. J. Cutan. Pathol. 2000, 27, 367-373. [CrossRef] [PubMed]

107. Lin, C.-Y.; Kuo, T.-T.; Chang, Y.-C. Comparative Immunohistochemical study of hidroacanthoma simplex and clonal seborrheic keratosis with GATA3 and P63. Am. J. Derm. 2021, 44, 17-20. [CrossRef]

108. Mazoujian, G.; Margolis, R. Immunohistochemistry of gross cystic disease fluid protein (GCDFP-15) in 65 benign sweat gland tumors of the skin. Am. J. Derm. 1988, 10, 28-35. [CrossRef]

109. Sekine, S.; Kiyono, T.; Ryo, E.; Ogawa, R.; Wakai, S.; Ichikawa, H.; Suzuki, K.; Arai, S.; Tsuta, K.; Ishida, M.; et al. Recurrent YAP1-MAML2 and YAP1-NUTM1 fusions in poroma and porocarcinoma. J. Clin. Invest. 2019, 129, 3827-3832. [CrossRef] [PubMed]

110. Agaimy, A.; Tögel, L.; Haller, F.; Zenk, J.; Hornung, J.; Märkl, B. YAP1-NUTM1 Gene fusion in porocarcinoma of the external auditory canal. Head Neck Pathol. 2020, 14, 982-990. [CrossRef]

111. Agaimy, A.; Stoehr, R.; Tögel, L.; Hartmann, A.; Cramer, T. YAP1-MAML2-Rearranged poroid squamous cell carcinoma (squamoid porocarcinoma) presenting as a primary parotid gland tumor. Head Neck Pathol. 2021, 15, 361-367. [CrossRef]

112. Szulzewsky, F.; Holland, E.C.; Vasioukhin, V. YAP1 and its fusion proteins in cancer initiation, progression and therapeutic resistance. Dev. Biol. 2021, 475, 205-221. [CrossRef] [PubMed]

113. Cavalieri, S.; Busico, A.; Capone, I.; Conca, E.; Dallera, E.; Quattrone, P.; Licitra, L.; Pruneri, G.; Bossi, P.; Perrone, F. Identification of potentially druggable molecular alterations in skin adnexal malignancies. J. Derm. 2019, 46, 507-514. [CrossRef] [PubMed]

114. Harms, P.W.; Hovelson, D.H.; Cani, A.K.; Omata, K.; Haller, M.J.; Wang, M.L.; Arps, D.; Patel, R.M.; Fullen, D.R.; Wang, M.; et al. Porocarcinomas harbor recurrent hras-activating mutations and tumor suppressor inactivating mutations. Hum. Pathol. 2016, 51, 25-31. [CrossRef] [PubMed]

115. Bosic, M.; Kirchner, M.; Brasanac, D.; Leichsenring, J.; Lier, A.; Volckmar, A.-L.; Oliveira, C.; Buchhalter, I.; Stögbauer, F.; Zivkovic-Perisic, S.; et al. Targeted molecular profiling reveals genetic heterogeneity of poromas and porocarcinomas. Pathology 2018, 50, 327-332. [CrossRef] [PubMed]

116. Denisova, E.; Westphal, D.; Surowy, H.M.; Meier, F.; Hutter, B.; Reifenberger, J.; Rütten, A.; Schulz, A.; Sergon, M.; Ziemer, M.; et al. Whole-exome sequencing in eccrine porocarcinoma indicates promising therapeutic strategies. Cancer Gene 2021, $2021,1-12$. [CrossRef]

117. Harrison, B.T.; Fowler, E.; Krings, G.; Chen, Y.-Y.; Bean, G.R.; Vincent-Salomon, A.; Fuhrmann, L.; Barnick, S.E.; Chen, B.; Hosfield, E.M.; et al. Pan-TRK Immunohistochemistry: A useful diagnostic adjunct for secretory carcinoma of the breast. am. J. Surg. Pathol. 2019, 43, 1693-1700. [CrossRef]

118. Yamamoto, H.; Nozaki, Y.; Sugii, A.; Taguchi, K.; Hongo, T.; Jiromaru, R.; Sato, M.; Nakano, T.; Hashimoto, K.; Fujiwara, M.; et al. Pan-tropomyosin receptor kinase immunoreactivity, ETV6-NTRK3 fusion subtypes, and RET rearrangement in salivary secretory carcinoma. Hum. Pathol. 2021, 109, 37-44. [CrossRef] 
119. Csanyi-Bastien, M.; Lanic, M.-D.; Beaussire, L.; Ferric, S.; François, A.; Meseure, D.; Jardin, F.; Wassef, M.; Ruminy, P.; Laé, M. Pan-TRK immunohistochemistry is highly correlated with NTRK3 gene rearrangements in salivary gland tumors. Am. J. Surg. Pathol. 2021, 45, 1487-1498. [CrossRef]

120. De la Fouchardière, A.; Tee, M.K.; Peternel, S.; Valdebran, M.; Pissaloux, D.; Tirode, F.; Busam, K.J.; LeBoit, P.E.; McCalmont, T.H.; Bastian, B.C.; et al. Fusion partners of NTRK3 affect subcellular localization of the fusion kinase and cytomorphology of melanocytes. Mod. Pathol. 2021, 34, 735-747. [CrossRef]

121. Baghai, F.; Yazdani, F.; Etebarian, A.; Garajei, A.; Skalova, A. Clinicopathologic and molecular characterization of mammary analogue secretory carcinoma of salivary gland origin. Pathol. Res. Pr. 2017, 213, 1112-1118. [CrossRef]

122. Taverna, C.; Baněčková, M.; Lorenzon, M.; Palomba, A.; Franchi, A.; Skalova, A.; Agaimy, A. MUC4 Is a valuable marker for distinguishing secretory carcinoma of the salivary glands from its mimics. Histopathol. 2021, 79, 315-324. [CrossRef]

123. Bishop, J.A.; Taube, J.M.; Su, A.; Binder, S.W.; Kazakov, D.V.; Michal, M.; Westra, W.H. Secretory carcinoma of the skin harboring ETV6 gene fusions: A cutaneous analogue to secretory carcinomas of the breast and salivary glands. Am. J. Surg. Pathol. 2017, 41, 62-66. [CrossRef] [PubMed]

124. Amin, S.M.; Beattie, A.; Ling, X.; Jennings, L.J.; Guitart, J. Primary Cutaneous mammary analog secretory carcinoma with ETV6-NTRK3 translocation. Am. J. Derm. 2016, 38, 842-845. [CrossRef] [PubMed]

125. Cocco, E.; Scaltriti, M.; Drilon, A. NTRK fusion-positive cancers and TRK inhibitor therapy. Nat. Rev. Clin. Oncol. 2018, 15, 731-747. [CrossRef] [PubMed]

126. Kastnerova, L.; Luzar, B.; Goto, K.; Grishakov, V.; Gatalica, Z.; Kamarachev, J.; Martinek, P.; Hájková, V.; Grossmann, P.; Imai, H.; et al. Secretory carcinoma of the skin: Report of 6 cases, including a case with a novel NFIX-PKN1 translocation. Am. J. Surg. Pathol. 2019, 43, 1092-1098. [CrossRef]

127. Krings, G.; Joseph, N.M.; Bean, G.R.; Solomon, D.; Onodera, C.; Talevich, E.; Yeh, I.; Grenert, J.P.; Hosfield, E.; Crawford, E.D.; et al. Genomic profiling of breast secretory carcinomas reveals distinct genetics from other breast cancers and similarity to mammary analog secretory carcinomas. Mod. Pathol. 2017, 30, 1086-1099. [CrossRef]

128. Suurmeijer, A.J.; Dickson, B.C.; Swanson, D.; Zhang, L.; Sung, Y.-S.; Huang, H.-Y.; Fletcher, C.D.; Antonescu, C.R. The histologic spectrum of soft tissue spindle cell tumors with NTRK3 gene rearrangements. Genes Chromosomes Cancer 2019, 58, 739-746. [CrossRef]

129. Rubin, B.P.; Chen, C.J.; Morgan, T.W.; Xiao, S.; Grier, H.E.; Kozakewich, H.P.; Perez-Atayde, A.R.; Fletcher, J.A. Congenital mesoblastic nephroma t $(12 ; 15)$ is associated with ETV6-NTRK3 gene fusion: Cytogenetic and Molecular relationship to congenital (infantile) fibrosarcoma. Am. J. Pathol. 1998, 153, 1451-1458. [CrossRef]

130. Knezevich, S.R.; Garnett, M.J.; Pysher, T.J.; Beckwith, J.B.; Grundy, P.E.; Sorensen, P.H. ETV6-NTRK3 gene fusions and trisomy 11 establish a histogenetic link between mesoblastic nephroma and congenital fibrosarcoma. Cancer Res. 1998, 58, 5046-5048.

131. Watanabe, N.; Kobayashi, H.; Hirama, T.; Kikuta, A.; Koizumi, S.; Tsuru, T.; Kaneko, Y. Cryptic t(12;15)(P13;Q26) Producing the ETV6-NTRK3 fusion gene and no loss of IGF2 imprinting in congenital mesoblastic nephroma with trisomy 11: Fluorescence in situ hybridization and IGF2 allelic expression analysis. Cancer Genet. Cytogenet. 2002, 136, 10-16. [CrossRef]

132. Skálová, A.; Vanecek, T.; Sima, R.; Laco, J.; Weinreb, I.; Perez-Ordonez, B.; Starek, I.; Geierova, M.; Simpson, R.H.W.; PassadorSantos, F.; et al. Mammary analogue secretory carcinoma of salivary glands, containing the ETV6-NTRK3 fusion gene: A hitherto undescribed salivary gland tumor entity. Am. J. Surg. Pathol. 2010, 34, 599-608. [CrossRef]

133. Fehr, A.; Löning, T.; Stenman, G. Mammary analogue secretory carcinoma of the salivary glands with ETV6-NTRK3 gene fusion. Am. J. Surg. Pathol. 2011, 35, 1600-1602. [CrossRef] [PubMed]

134. Tognon, C.; Knezevich, S.R.; Huntsman, D.; Roskelley, C.D.; Melnyk, N.; Mathers, J.A.; Becker, L.; Carneiro, F.; MacPherson, N.; Horsman, D.; et al. Expression of the ETV6-NTRK3 gene fusion as a primary event in human secretory breast carcinoma. Cancer Cell 2002, 2, 367-376. [CrossRef]

135. Makretsov, N.; He, M.; Hayes, M.; Chia, S.; Horsman, D.E.; Sorensen, P.H.B.; Huntsman, D.G. A fluorescence in situ hybridization study of ETV6-NTRK3 fusion gene in secretory breast carcinoma. Genes Chromosomes Cancer 2004, 40, 152-157. [CrossRef] [PubMed]

136. Yamamoto, H.; Yoshida, A.; Taguchi, K.; Kohashi, K.; Hatanaka, Y.; Yamashita, A.; Mori, D.; Oda, Y. ALK, ROS1 and NTRK3 gene rearrangements in inflammatory myofibroblastic tumours. Histopathology 2016, 69, 72-83. [CrossRef] [PubMed]

137. Alassiri, A.H.; Ali, R.H.; Shen, Y.; Lum, A.; Strahlendorf, C.; Deyell, R.; Rassekh, R.; Sorensen, P.H.; Laskin, J.; Marra, M.; et al. ETV6-NTRK3 is expressed in a subset of ALK-negative inflammatory myofibroblastic tumors. Am. J. Surg. Pathol. 2016, 40, 1051-1061. [CrossRef] [PubMed]

138. Brenca, M.; Rossi, S.; Polano, M.; Gasparotto, D.; Zanatta, L.; Racanelli, D.; Valori, L.; Lamon, S.; Dei Tos, A.P.; Maestro, R. Transcriptome sequencing identifies ETV6-NTRK3 as a gene fusion involved in GIST. J. Pathol. 2016, 238, 543-549. [CrossRef]

139. Punnett, H.H.; Tomczak, E.Z.; Pawel, B.R.; de Chadarevian, J.P.; Sorensen, P.H. ETV6-NTRK3 Gene fusion in metastasizing congenital fibrosarcoma. Med. Pediatr. Oncol. 2000, 35, 137-139. [CrossRef]

140. Knezevich, S.R.; McFadden, D.E.; Tao, W.; Lim, J.F.; Sorensen, P.H. A novel ETV6-NTRK3 gene fusion in congenital fibrosarcoma. Nat. Genet. 1998, 18, 184-187. [CrossRef] [PubMed]

141. Yeh, I.; Tee, M.K.; Botton, T.; Shain, A.H.; Sparatta, A.J.; Gagnon, A.; Vemula, S.S.; Garrido, M.C.; Nakamaru, K.; Isoyama, T.; et al. NTRK3 kinase fusions in spitz tumours. J. Pathol. 2016, 240, 282-290. [CrossRef] 
142. Zhang, J.; Wu, G.; Miller, C.P.; Tatevossian, R.G.; Dalton, J.D.; Tang, B.; Orisme, W.; Punchihewa, C.; Parker, M.; Qaddoumi, I.; et al. Whole-genome sequencing identifies genetic alterations in pediatric low-grade gliomas. Nat. Genet. 2013, 45, 602-612. [CrossRef] [PubMed]

143. Wu, G.; Diaz, A.K.; Paugh, B.S.; Rankin, S.L.; Ju, B.; Li, Y.; Zhu, X.; Qu, C.; Chen, X.; Zhang, J.; et al. The genomic landscape of diffuse intrinsic pontine glioma and pediatric non-brainstem high-grade glioma. Nat. Genet. 2014, 46, 444-450. [CrossRef] [PubMed]

144. Leeman-Neill, R.J.; Kelly, L.M.; Liu, P.; Brenner, A.V.; Little, M.P.; Bogdanova, T.I.; Evdokimova, V.N.; Hatch, M.; Zurnadzy, L.Y.; Nikiforova, M.N.; et al. ETV6-NTRK3 is a common chromosomal rearrangement in radiation-associated thyroid cancer. Cancer 2014, 120, 799-807. [CrossRef] [PubMed]

145. Andreasen, S.; Skálová, A.; Agaimy, A.; Bishop, J.A.; Laco, J.; Leivo, I.; Franchi, A.; Larsen, S.R.; Erentaite, D.; Ulhøi, B.P.; et al. ETV6 Gene rearrangements characterize a morphologically distinct subset of sinonasal low-grade non-intestinal-type adenocarcinoma: A novel translocation-associated carcinoma restricted to the sinonasal tract. Am. J. Surg. Pathol. 2017, 41, 1552-1560. [CrossRef] [PubMed]

146. Kazakov, D.V.; Bisceglia, M.; Calonje, E.; Hantschke, M.; Kutzner, H.; Mentzel, T.; Michal, M.; Mukensnabl, P.; Spagnolo, D.V.; Rütten, A.; et al. Tubular adenoma and syringocystadenoma papilliferum: A reappraisal of their relationship. an interobserver study of a series, by a panel of dermatopathologists. Am. J. Derm. 2007, 29, 256-263. [CrossRef]

147. Watanabe, Y.; Shido, K.; Niihori, T.; Niizuma, H.; Katata, Y.; Iizuka, C.; Oba, D.; Moriya, K.; Saito-Nanjo, Y.; Onuma, M.; et al. Somatic BRAF c.1799T>A p.V600E mosaicism syndrome characterized by a linear syringocystadenoma papilliferum, anaplastic astrocytoma, and ocular abnormalities. Am. J. Med. Genet. A 2016, 170, 189-194. [CrossRef] [PubMed]

148. Aslam, A.; Salam, A.; Griffiths, C.E.M.; McGrath, J.A. Naevus sebaceus: A mosaic rasopathy. Clin. Exp. Derm. 2014, 39, 1-6. [CrossRef]

149. Friedman, B.J.; Sahu, J.; Solomides, C.C.; Connolly, D.M.; Lee, J.B. Contiguous verrucous proliferations in syringocystadenoma papilliferum: A retrospective analysis with additional evaluation via mutation-specific BRAFV600E immunohistochemistry. J. Cutan. Pathol. 2018, 45, 212-216. [CrossRef] [PubMed]

150. Groesser, L.; Herschberger, E.; Ruetten, A.; Ruivenkamp, C.; Lopriore, E.; Zutt, M.; Langmann, T.; Singer, S.; Klingseisen, L.; Schneider-Brachert, W.; et al. Postzygotic HRAS and KRAS mutations cause nevus sebaceous and schimmelpenning syndrome. Nat. Genet. 2012, 44, 783-787. [CrossRef]

151. Shen, A.-S.; Peterhof, E.; Kind, P.; Rütten, A.; Zelger, B.; Landthaler, M.; Berneburg, M.; Hafner, C.; Groesser, L. Activating mutations in the RAS/mitogen-activated protein kinase signaling pathway in sporadic trichoblastoma and syringocystadenoma papilliferum. Hum. Pathol. 2015, 46, 272-276. [CrossRef]

152. Liau, J.-Y.; Tsai, J.-H.; Huang, W.-C.; Lan, J.; Hong, J.-B.; Yuan, C.-T. BRAF and KRAS Mutations in tubular apocrine adenoma and papillary eccrine adenoma of the skin. Hum. Pathol. 2018, 73, 59-65. [CrossRef] [PubMed]

153. Konstantinova, A.M.; Kyrpychova, L.; Nemcova, J.; Sedivcova, M.; Bisceglia, M.; Kutzner, H.; Zamecnik, M.; Sehnalkova, E.; Pavlovsky, M.; Zateckova, K.; et al. Syringocystadenoma papilliferum of the anogenital area and buttocks: A report of 16 cases, including human papillomavirus analysis and HRAS and BRAF V600 mutation studies. Am. J. Derm. 2019, 41, 281-285. [CrossRef] [PubMed]

154. Long, T.; Bonomo, B.; Shearer, S.; Welton, W.; Massullo, R.; Gibbons, G. Is syringocystadenoma papilliferum incidental in this verrucous carcinoma? Case. Rep. Pathol. 2019, 2019, 1783758. [CrossRef] [PubMed]

155. Alegría-Landa, V.; Jo-Velasco, M.; Santonja, C.; Eraña, I.; Vergara-Sanchez, A.; Kutzner, H.; Requena, L. Syringocystadenoma papilliferum associated with verrucous carcinoma of the skin in the same lesion: Report of four cases. J. Cutan. Pathol. 2020, 47, 12-16. [CrossRef]

156. Hsieh, M.-S.; Bishop, J.A.; Wang, Y.-P.; Poh, C.F.; Cheng, Y.-S.L.; Lee, Y.-H.; Jin, Y.-T.; Chang, J.Y.F. Salivary Sialadenoma papilliferum consists of two morphologically, immunophenotypically, and genetically distinct subtypes. Head Neck Pathol. 2020, 14, 489-496. [CrossRef] [PubMed]

157. Hsieh, M.-S.; Bishop, J.A.; Yu Fong Chang, J. Sialadenoma papilliferum. Surg. Pathol. Clin. 2021, 14, 43-51. [CrossRef]

158. Trager, M.H.; Jurkiewicz, M.; Khan, S.; Niedt, G.W.; Geskin, L.J.; Carvajal, R.D. A case report of papillary digital adenocarcinoma with BRAFV600E mutation and quantified mutational burden. Am. J. Derm. 2021, 43, 57-59. [CrossRef]

159. Agni, M.; Raven, M.L.; Bowen, R.C.; Laver, N.V.; Chevez-Barrios, P.; Milman, T.; Eberhart, C.G.; Couch, S.; Bennett, D.D.; Albert, D.M.; et al. An update on endocrine mucin-producing sweat gland carcinoma: Clinicopathologic study of 63 cases and comparative analysis. Am. J. Surg. Pathol. 2020, 44, 1005-1016. [CrossRef] [PubMed]

160. Zembowicz, A.; Garcia, C.F.; Tannous, Z.S.; Mihm, M.C.; Koerner, F.; Pilch, B.Z. Endocrine mucin-producing sweat gland carcinoma: Twelve new cases suggest that it is a precursor of some invasive mucinous carcinomas. Am. J. Surg. Pathol. 2005, 29, 1330-1339. [CrossRef]

161. Goto, K.; Anan, T.; Nakatsuka, T.; Kaku, Y.; Sakurai, T.; Fukumoto, T.; Kimura, T.; Shibata, A. Low-grade neuroendocrine carcinoma of the skin (primary cutaneous carcinoid tumor) as a distinctive entity of cutaneous neuroendocrine tumors: A clinicopathologic study of 3 cases with literature review. Am. J. Derm. 2017, 39, 250-258. [CrossRef]

162. Chou, Y.-H.; Chang, Y.-C.; Huang, Y.-L.; Wu, C.-T. Endocrine mucin-producing sweat gland carcinoma with GATA3 expression: Report of two cases. Pathol. 2017, 49, 805-808. [CrossRef] 
163. Quattrochi, B.; Russell-Goldman, E. Utility of Insulinoma-Associated Protein 1 (INSM1) and Mucin 2 (MUC2) Immunohistochemistry in the distinction of endocrine mucin-producing sweat gland carcinoma from morphologic mimics. Am. J. Derm. 2021. [CrossRef] [PubMed]

164. Held, L.; Ruetten, A.; Kutzner, H.; Palmedo, G.; John, R.; Mentzel, T. Endocrine mucin-producing sweat gland carcinoma: Clinicopathologic, immunohistochemical, and molecular analysis of 11 cases with emphasis on myb immunoexpression. J. Cutan. Pathol. 2018, 28, 653-657. [CrossRef] [PubMed]

165. Abdulkader, M.; Kuhar, M.; Hattab, E.; Linos, K. GATA3 positivity in endocrine mucin-producing sweat gland carcinoma and invasive mucinous carcinoma of the eyelid: Report of 2 cases. Am. J. Derm. 2016, 38, 789-791. [CrossRef]

166. Shon, W.; Salomão, D.R. WT1 Expression in endocrine mucin-producing sweat gland carcinoma: A study of 13 cases. Int. J. Derm. 2014, 53, 1228-1234. [CrossRef]

167. Mathew, J.G.; Bowman, A.S.; Saab, J.; Busam, K.J.; Nehal, K.; Pulitzer, M. Next generation sequencing analysis suggests varied multistep mutational pathogenesis for endocrine mucin producing sweat gland carcinoma with comments on INSM1 and MUC2 suggesting a conjunctival origin. J. Am. Acad. Derm. 2021. [CrossRef]

168. Qin, H.; Moore, R.F.; Ho, C.-Y.; Eshleman, J.; Eberhart, C.G.; Cuda, J. Endocrine mucin-producing sweat gland carcinoma: A study of 11 cases with molecular analysis. J. Cutan. Pathol. 2018, 45, 681-687. [CrossRef]

169. Cornejo, K.M.; Hutchinson, L.; Meng, X.; O’Donnell, P.; Deng, A. Endocrine mucin-producing sweat gland carcinoma of the eyelid: A report of a case with molecular analysis. Am. J. Derm. 2016, 38, 636-638. [CrossRef] [PubMed]

170. De Pinieux, G.; Karanian, M.; Le Loarer, F.; Le Guellec, S.; Chabaud, S.; Terrier, P.; Bouvier, C.; Batistella, M.; Neuville, A.; Robin, Y.-M.; et al. Nationwide incidence of sarcomas and connective tissue tumors of intermediate malignancy over four years using an expert pathology review network. PLoS ONE 2021, 16, e0246958. [CrossRef] [PubMed]

171. Battistella, M.; Balme, B.; Jullie, M.-L.; Zimmermann, U.; Carlotti, A.; Crinquette, M.; Crinquette, M.; Frouin, E.; Macagno, N.; Lamant, L.; et al. Impact of expert pathology review in skin adnexal carcinoma diagnosis: Analysis of 2573 patients from the french caraderm network. Eur. J. Cancer 2021, in press. 